\title{
Genetic Variation, Heritability and Genetic Advance Among Semi-Dwarf Tef [Eragrostis tef (Zucc.) Trotter] Recombinant Inbred Lines with Emphasis to Lodging
}

\author{
Getahun Bekana $^{1,}$,, Kebebew Assefa ${ }^{1,2}$ \\ ${ }^{1}$ Ethiopian Institute of Agricultural Research, Holeta Agricultural Research Center, Holeta, Ethiopia \\ ${ }^{2}$ Ethiopian Institute of Agricultural Research, Debre Zeit Agricultural Research Center, Debre Zeit, Ethiopia \\ Email address: \\ getahunbekana2006@gmail.com (G. Bekana),Kebebew.assefa@yahoo.com (K. Assefa) \\ * Corresponding author
}

To cite this article:

Getahun Bekana, Kebebew Assefa. Genetic Variation, Heritability and Genetic Advance Among Semi-Dwarf Tef [Eragrostis tef (Zucc.)

Trotter] Recombinant Inbred Lines with Emphasis to Lodging. American Journal of Life Sciences. Vol. 9, No. 5, 2021, pp. 92-104.

doi: 10.11648/j.ajls.20210905.11

Received: August 21, 2021; Accepted: September 3, 2021; Published: September 11, 2021

\begin{abstract}
Tef is the foremost cereal crop largely produced and consumed mostly in Ethiopia. It is grown on more than 3.1 million hectares annually. However, it's productivity relatively low $(1.85 \mathrm{t} / \mathrm{ha})$. On the other hand, it gained recently global popularity "Super grain" as healthy and performance food due to its gluten free especially for celiac disease, diabetic and gluten allergy people. It has also high mineral contents like iron for anemia, bone and heart health as well as brain function. Lodging is a major constraint which affect both yields and quality of the grain as well as the straw. This experiment was led to assess genetic variability between the lines relating to lodging and other yield related traits. A total of forty-nine recombinant inbred lines were tested for 16 traits using simple lattice design on two sites. All the traits measured over the sites displayed highly significant differences among the lines except fertile tiller per plant, while their environmental interaction effect also highly significant for most of the traits measured. Grain yield showed the highest phenotypic coefficients of variation (PCV) $(26.36 \%)$ followed by above ground biomass $(23.16 \%)$, while the remaining traits showed low $(<10 \%)$ to moderate $(10-20 \%)$. Moderate (10-20\%) genotypic coefficient of variation was recognized for above ground biomass. Plant height and panicle length showed high broad sense heritability $\left(\mathrm{H}^{2}\right)(>60 \%)$, whereas half of the remained traits showed low $(<30 \%)$ and moderate $(30 \%$ to $60 \%)$ heritability. Genetic advance as percent of the mean (GAM) was the highest for above ground biomass $(>17.02 \%)$ and least for number of branches per panicle $(0.09 \%)$. From all the traits evaluated in this study, plant height, panicle length showed high $\mathrm{H}^{2}$ and aboveground biomass performs relatively high values of GCV, PCV and GAM. Therefore, these traits are important for selection and further improvements. This study revealed that four recombinant inbred lines had higher yield and low lodging index than local as well as standard checks.
\end{abstract}

Keywords: Fertile, Genotypic Coefficient, Interaction, Recombinant, Traits

\section{Introduction}

Tef [Eragrostis tef (Zucc.) Trotter] belongs to the family Poaceae, subfamily Chloridoideae, genus Eragrostis with binomial nomenclature of Eragrostis tef (Zucc.) Trotter. It is an allotetraploid $(2 \mathrm{n}=4 \mathrm{X}=40)$, self-pollinated with bisexual florets of chasmogamous pollination behavior, and $\mathrm{C}_{4}$ plant $[1,2]$. Its center of origin and diversity is in Ethiopia [3]. Fifty-four of the 350 Eragrostis species, including the 14 endemic species were found in Ethiopia where they believed to been domesticated by pre-Semitic inhabitants between 4000 and $1000 \mathrm{BC}$ [4-6].

Tef is the main cereal crop widely produced and consumed in Ethiopia and favored by millions of local smallholder farmers [7]. In terms of area of cultivation, it is the leading cereal crop followed by maize and wheat. According to the Central Statistical Agency [8], the area covered by tef during the $2019 / 2020$ cropping season was over 3.1 million hectares or $30 \%$ of the total area occupied by cereals in the country.

Despite being a main food for many people in this country 
for long periods of time, tef expanded and renown as a food crop in other parts of the world lately. This interest is mainly associated with its gluten-free grains and its nutritive value that is normally comparable with other common cereals [912]. However, it is also growing as a pasture crop in several countries [13]. The straw from tef is a precious source of livestock feed because it is more palatable and nutritious than that of wheat and barley [14].

Tef is a very adaptable crop to different agro-ecologies being extensively grown from sea level up to 2800 m.a.s.l. with reasonable resilience to both drought and water logging [13]. The national average yield of tef is about 1.85 ton per hectare [8], but it has a capability to give up to 6 ton per hectare of grain yield if the lodging problem is resolved $[4,7$, 15]. The main yield restrictive factors are un availability of cultivars that are tolerant to lodging and shortage of improved varieties [16].

Besides, the grains are frequently lost during harvesting and threshing process because of their minute size and traditional cultural practices [17]. Tef has thin, tall and weak stem which simply expose to lodging at strong wind or rain. In addition, lodging hinders the use of high input husbandry practices since the application of increased amounts of nitrogen fertilizer to boost the yield results in severe lodging [16].

Lodging greatly reduces both yields and quality of the grain as well as the straw. It is reported to decrease tef grain yield by approximately 15 to $45 \%$ depending on the weather condition and inherent nature of the variety used [18]; it also hampers both manual and mechanical harvesting [16]. Using lower seed rates and late sowing dates relatively decreases the problem of lodging. Although, various attempts have been made by the research community to develop lodging-resistant tef cultivars $[13,19]$, no cultivar with reasonable lodging resistance has been obtained to-date except a novel tef mutant named kegne, and GA-10-3 which have a semi-dwarf phenotype, resulting in increased lodging tolerance [20].

The tef germplasm accessions showed wide genetic variability in phonological, morphological and agronomical traits $[9,13,21]$. In spite of this, there has been lack of sufficient variability in the tef germplasm for some valuable traits such as lodging and shattering resistance. Since recent past, a chemical mutagen, ethyl methane sulphonate (EMS), has been successfully utilized to induce semi-dwarf tef variants with lodging resistance as well as tolerance to aluminum toxicity and other acidity-related soil fertility problems [22-25]. The first semi-dwarf lodging-tolerant tef line, called kegne developed from an ethyl methane sulphonate-mutagenized population [20].

Some important works have also reported based on morphological, molecular and biochemical markers. According to $[26,27]$, many efforts made in the past to implement different techniques and tools in order to improve tef. The variations noted in panicle length $(14-65 \mathrm{~cm})$, culm length $(11-82 \mathrm{~cm})$, plant height $(31-155 \mathrm{~cm})$, culm thickness $(1.2-4.5 \mathrm{~mm})$ all indicate the potential for developing lodging-resistant genotypes through gene re-combination as suggested by [4].
Exertions accomplished from 1950's to now were empowered the development and release of over 51 improved varieties to the farming communities [28]. Nevertheless, development of high yielding and lodging tolerant tef varieties, adapting to the changing climate remains to be the primary focus of tef research [29, 30]. Especially, semi-dwarf tef types did not studied much yet and there is no lodging tolerant as well as resistant tef [31]. Thus, this study led out with the subsequent objective:

To estimate the level of genetic variation among selected semi-dwarf tef recombinant inbred lines with emphasis on lodging tolerance, yield and yield components, and thereby generate information as well as identify superior inbred lines.

\section{Materials and Methods}

\subsection{Descriptions of Experimental Locations}

The field experiment was conducted on two sites (Debre Zeit and Holetta) in the central parts of Ethiopia during the 2017 cropping season (July to December). Debre Zeit is located at $47 \mathrm{~km}$ to south east of Addis Ababa, while Holetta is located at $42 \mathrm{~km}$ to the west of Addis Ababa. DZARC found at $\left(8^{\circ} 44^{\prime} \mathrm{N}, 38^{\circ} 58^{\prime} \mathrm{E}\right.$ and 1860 m.a.s.l) whereas, HARC found at $\left(9^{\circ} 03^{\prime} \mathrm{N}, 38^{\circ} 30^{\prime} \mathrm{E}\right.$ and 2400 m.a.s.l) latitude, longitude and altitude, respectively. Both sites had been their own agro-ecologies which was best to this study. Debre Zeit receives mean annual rainfall of $832 \mathrm{~mm}$ during the main growing season with maximum and minimum mean annual temperature of $24.3^{\circ} \mathrm{C}$ and $8.9^{\circ} \mathrm{C}$, respectively. The trial field of Debre Zeit categorized as heavy black soil (Vertisol) with a $\mathrm{pH}$ of 6.9 and described as very fine montmorillonitic typic pellustert with very high moisture retention capacity $[32,33]$.

In contrast, Holeta often obtains annual total rainfall 1100 $\mathrm{mm}$ with maximum and minimum mean annual temperature of $24.1^{\circ} \mathrm{C}$ and $6.6^{\circ} \mathrm{C}$, respectively. The trial field at this site characterize by light red soil (Andosol) with a $\mathrm{pH}$ of 6.3 and good moisture holding capacity. The meteorological conditions throughout the growing season were favorable and the trial received sufficient amount of rain for normal growth of tef at each of the trial sites.

\subsection{Planting Materials}

These experimental plant materials comprised 49 semidwarf tef recombinant inbred lines including local and standard checks. These included 45 recombinant inbred lines (RIL) derived from the crosses of DZ-01-192 x GA10-3, the two parents (pure lines), one standard and local check (Table 1).

The RILs are descendants of the intra-specific cross through continuous maintenance of progenies up to the seventh filial generation (F7) through selfing using F2derived single-seed-decent breeding method. The tef cultivar DZ-01-192 is late maturing, thick culmed, tall, has loose panicle and white seed color. GA-10-3 is a mutant line developed through mutation breeding by using Ethyl 
methane sulphonate (EMS) assisted by Targeted Induced Local Lesions IN Genomes (TILLING) method and introduced from university of Bern (Switzerland). It has lodging tolerance characters, early maturity, semi-dwarf structure and pale white seed color. The materials kindly supplied by Debre Zeit agricultural research center, in Ethiopia. I have duly acknowledged DZARC for their kindness.

Table 1. Experimental materials

\begin{tabular}{|c|c|c|c|}
\hline No. & Recombinant Inbred Lines SD-Tef & No. & Recombinant Inbred Lines SD-Tef \\
\hline 1 & DZ-01-192 x GA-10-3 (RIL \# 1) & 26 & DZ-01-192 x GA-10-3 (RIL \# 58) \\
\hline 2 & DZ-01-192 x GA-10-3 (RIL \# 2) & 27 & DZ-01-192 x GA-10-3 (RIL \# 68) \\
\hline 3 & DZ-01-192 x GA-10-3 (RIL \# 4) & 28 & DZ-01-192 x GA-10-3 (RIL \# 75) \\
\hline 4 & DZ-01-192 x GA-10-3 (RIL \# 5) & 29 & DZ-01-192 x GA-10-3 (RIL \# 160) \\
\hline 5 & DZ-01-192 x GA-10-3 (RIL \# 6) & 30 & DZ-01-192 x GA-10-3 (RIL \# 161) \\
\hline 6 & DZ-01-192 x GA-10-3 (RIL \# 8) & 31 & DZ-01-192 x GA-10-3 (RIL \# 162) \\
\hline 7 & DZ-01-192 x GA-10-3 (RIL \# 12) & 32 & DZ-01-192 x GA-10-3 (RIL \# 166) \\
\hline 9 & DZ-01-192 x GA-10-3 (RIL \# 15) & 34 & DZ-01-192 x GA-10-3 (RIL \# 171) \\
\hline 10 & DZ-01-192 x GA-10-3 (RIL \# 16) & 35 & DZ-01-192 x GA-10-3 (RIL \# 172) \\
\hline 11 & DZ-01-192 x GA-10-3 (RIL \# 19) & 36 & DZ-01-192 x GA-10-3 (RIL \# 174) \\
\hline 12 & DZ-01-192 x GA-10-3 (RIL \# 20) & 37 & DZ-01-192 x GA-10-3 (RIL \# 175) \\
\hline 13 & DZ-01-192 x GA-10-3 (RIL \# 21) & 38 & DZ-01-192 x GA-10-3 (RIL \# 178) \\
\hline 14 & DZ-01-192 x GA-10-3 (RIL \# 22) & 39 & DZ-01-192 x GA-10-3 (RIL \# 179) \\
\hline 15 & DZ-01-192 x GA-10-3 (RIL \# 24) & 40 & DZ-01-192 x GA-10-3 (RIL \# 180) \\
\hline 17 & DZ-01-192 x GA-10-3 (RIL \# 27) & 42 & DZ-01-192 x GA-10-3 (RIL \# 185) \\
\hline 18 & DZ-01-192 x GA-10-3 (RIL \# 28) & 43 & DZ-01-192 x GA-10-3 (RIL \# 195) \\
\hline 19 & DZ-01-192 x GA-10-3 (RIL \# 33) & 44 & DZ-01-192 x GA-10-3 (RIL \# 203) \\
\hline 20 & DZ-01-192 x GA-10-3 (RIL \# 41) & 45 & DZ-01-192 x GA-10-3 (RIL \# 262) \\
\hline 21 & DZ-01-192 x GA-10-3 (RIL \# 44) & 46 & Boset (standard check) \\
\hline 22 & DZ-01-192 x GA-10-3 (RIL \# 45) & 47 & DZ-01-192 (parental check) \\
\hline 23 & DZ-01-192 x GA-10-3 (RIL \# 48) & 48 & GA-10-3 (parental check) \\
\hline 24 & DZ-01-192 x GA-10-3 (RIL \# 52) & 49 & Local Check \\
\hline 25 & DZ-01-192 x GA-10-3 (RIL \# 57) & & \\
\hline
\end{tabular}

*SD: - Semi-dwarf tef; DZ-01: -Debre Zeit tef cultivar released through selection; GA-10-3: -Mutant elite tef line. Source of all material were from cross of (DZ-01-192 x GA-10-3) and $\mathrm{F}_{7}$ progeny of 2016-year gained from Debre Zeit center.

\subsection{Experimental Design, Layout and Management}

The field experiments conducted using $7 \times 7$ simple lattice designs at both locations. Each plot comprised of $1 \mathrm{~m}^{2}$ areas and five rows of $1 \mathrm{~m}$ length with an inter-row spacing of $0.2 \mathrm{~m}$. The distances between plot as well as intra block were $1 \mathrm{~m}$, whereas $1.5 \mathrm{~m}$ between replications. The tef recombinant inbred lines settled to plots at random within each replication. Sowing was done on 13 August, 25 July 2017 at Debre Zeit and Holetta research center, respectively. As per the research recommendations, $15 \mathrm{~kg} / \mathrm{ha}$ seed rate was used for both locations.
The fertilizer rate used for each location recommended depending on the type of soil. The fertilizers used for Holetta (light red soil) were $40 \mathrm{~kg} \mathrm{~N}, 60 \mathrm{~kg} \mathrm{P}_{2} \mathrm{O}_{5}$, and $11 \mathrm{~kg} \mathrm{~S}$ per hectare, as well as $60 \mathrm{~kg} \mathrm{~N}, 60 \mathrm{~kg} \mathrm{P}_{2} \mathrm{O}_{5}$ and $11 \mathrm{~kg} \mathrm{~S}$ per hectare for Debre Zeit (Vertisol). All NPS were applied at planting with a rate of $158 \mathrm{~kg} / \mathrm{ha}$ and the remaining urea applied at the rate of $22 \mathrm{~kg} / \mathrm{ha}$ for HARC and $65 \mathrm{~kg} / \mathrm{ha}$ for DZARC. Half of the urea applied at sowing, while the remaining half applied at tillering. Hand weeding and other management practices were performed as required including metrological data (Table 2).

Table 2. Mean monthly rainfall and temperature during cropping season at both locations of the experiments.

\begin{tabular}{|c|c|c|c|c|c|c|c|c|c|}
\hline \multirow{2}{*}{ Locations } & \multirow{2}{*}{\multicolumn{2}{|c|}{ Weather parameters }} & \multicolumn{7}{|c|}{ Months of the cropping season } \\
\hline & & & July & Aug & Sept & Oct & Nov & Dec & Means \\
\hline \multirow{3}{*}{ Holeta } & Rain Fall (mm) & & 172.8 & 311.4 & 244 & 29 & 0 & 0 & 126.2 \\
\hline & \multirow{2}{*}{ Temp. ${ }^{\circ} \mathrm{C}$} & $\max$ & 22.1 & 21.7 & 22.6 & 24.2 & 24 & 23.1 & 23.1 \\
\hline & & Min & 8.8 & 10.4 & 8.3 & 7.8 & 2.8 & 6.5 & 6.5 \\
\hline \multirow{3}{*}{ Debre Zeit } & Rain Fall (mm) & & 262.3 & 200.2 & 115.2 & 19 & 0 & 0 & 99.5 \\
\hline & \multirow{2}{*}{ Temp. ${ }^{\circ} \mathrm{C}$} & $\max$ & 23.9 & 21.8 & 24.5 & 26.5 & 26.2 & 24.9 & 24.9 \\
\hline & & Min & 14.6 & 14.3 & 14 & 11.1 & 8.3 & 11.6 & 11.6 \\
\hline
\end{tabular}

Source: DZARC and HARC Meteorology stations (2017).

\subsection{Data Collected}

Data collected from sixteen quantitative traits including seven traits taken on plot basis and nine traits assessed on randomly taken five plants of tef from the central rows of each plot. For individual plant trait sampled, averages of data 
from the five random samples of plants per plot used for statistical analyses.

The following data taken from plot basis:

Days to heading/ panicle emergence (DH): Number of days from seedling emergence to the appearance of the tips (about $5 \mathrm{~cm}$ ) of the main shoot panicle on $50 \%$ of the plants in a plot. Note that tef panicle appears without showing the booting stage, which is unlike the other small cereals like wheat and barley, but similar to that in rice.

Days to maturity (DM): Number of days from seedling emergence to physiological maturity as judged by the change to straw color of the vegetative parts on $75 \%$ of the plants in the plot.

Grain filling period (GFP): This computed as the difference between the days to panicle emergence and that to maturity.

Above ground biomass yield (ABM): The total dry weight in kilogram of the above ground biomass per plot before threshing.

Grain yield (GY): The entire plot of grains weight in kilogram after threshing and sun drying.

Harvest index (HI): The ratio of grain yield to the total biomass in percent.

Lodging index (LI): lodging assessment was performed as suggested by Caldicott and Nuttall [34] as follows:

$$
\mathrm{l} \mathrm{i}=\frac{\text { Sum (LS } * \text { Respective \%age of Area Lodged) }}{5}
$$

Lodging score (LS) was recorded on a $0-5$ scale as the degree of leaning from the upright position and whereby zero=completely upright non-lodged plants and five $=$ completely flat on the ground. The severity of lodging for each degree assessed as the proportion in percent of plants in a plot manifesting each degree of lodging. Finally, the lodging index for each plot was computed as the average of the product sum of each degree of lodging and the corresponding severity as indicated in the formula above.

The following observations recorded based on measurements made on five randomly taken and pre-tagged plants from the three central rows of each plots.

Plant height (PH): - The length of the plant in centimeter from ground level to the tip of the panicle.

Panicle length (PL): - The length in centimeter from the node where the first panicle branch starts to the tip of the panicle.

Culm length (CL): - The length in centimeter from ground level to the node where the first panicle branch starts.

Peduncle length (PDL): - The length in centimeter of the top most culm internode spanning from the last culm node until the start of the first panicle branch. It stretches from the node where the flag leaf starts to where the first panicle branch starts.

Second basal culm internode length (SCIL): The length in centimeter of the second basal culm internode.

Second basal culm diameter (SCID): The diameter in millimeter of the second basal culm internode measured using caliper.
Fertile tiller number per plant (NFT): - Counts of the panicle-bearing tillers of pre tagged main plants that have produced a fertile panicle.

Numbers of branches per main panicle (NBP): - Counts of the total number of branches per main panicle from bottom to top.

Number of spikelets per panicle (NSP): - It is the number of spikelets counted on the panicle.

\subsection{Statistical Analyses}

Tests of homogeneity and normality of error variances were done mainly using relationships of predicted means and residuals for all traits. ANOVA were done for single location as well as for the combined over locations (Tables 3 and 4). For combined analysis of variance over locations, the homogeneity of error variance was tested using F-max test method of Hartley [35], which requires independent random samples of the same size from normally distributed populations. It is based on the ratio of the larger mean square of error (MSE) from the separate analysis of variance to the smaller mean square of error given by the following formula:

$$
\text { Fmax }=\frac{\text { Largest MSE }}{\text { Smallest MSE }}
$$

If the calculated value of Fmax was less than three, it means that the ratio of the highest error mean square is not threefold larger than the smallest error mean square, and this indicates that the variance was considered homogenous thereby making it to possible to proceed with the combined analysis of variance [36].

Estimates of coefficients of phenotypic and genotypic variances, heritability and genetic advance done from mean square value and grand mean for each trait [37].

\subsubsection{Analysis of Variance}

All measured traits using simple lattice design were subjected to analysis of variance (ANOVA) of SAS software version 9.3 [38]. Total variability present among the recombinant inbred lines for each of the traits were partitioned into known (treatment) and unknown (residual) effects following the standard procedures of ANOVA using the following model according to Gomez and Gomez [36] indicated. After two error terms (Mean square error of block $\left(E_{b}\right)$ and Mean square of Experimental error $\left.\left(E_{e}\right)\right)$ calculated from combined ANOVA analysis.

Comparing $\mathrm{E}_{\mathrm{b}}$ with $\mathrm{E}_{\mathrm{e}}$; If $\mathrm{E}_{\mathrm{b}}>\mathrm{E}_{\mathrm{e}}$ an adjustment of the treatments were carried out, otherwise if $\mathrm{E}_{\mathrm{b}}<\mathrm{E}_{\mathrm{e}}$ no need of an adjustment of the treatments and the block effect is negligible then the data can be analyzed by RCBD, using replication as block. The SAS program for analyzing lattice design consists of two parts. In the first, PROC GLM was used to calculate unadjusted block SS (TYPE I SSSequential SS), adjusted block SS (TYPE III SS), unadjusted treatment SS, and intra-block error. To calculate the unadjusted block SS from TYPE I SS, the order in which variables were entered into the model statement is important. The block was entered before the treatment in the model 
statement. These estimates were used in the second part of the program to calculate the adjusted treatment SS, adjusted means, and the average effective error, respectively [36].

The comparison of mean performance of genotypes was done following the significance of mean squares using Duncan's Multiple Range Test (DMRT). Genotypic, environmental and phenotypic variances were estimated according to Falconer [39] as follows:

Genotypic variance for single location $\sigma^{2} \mathrm{~g}=\frac{\mathrm{MSg}-\mathrm{MSe}}{\mathrm{r}}$; Interaction variance $\sigma^{2} \mathrm{I}=\frac{\text { MSI - Mse }}{\mathrm{r}}$

Over locations genotypic variance $\sigma^{2} \mathrm{~g}=\frac{\mathrm{MSg}-\mathrm{MSI}}{\mathrm{rl}}$;

Environmental variance $\sigma^{2} \mathrm{e}=\frac{\mathrm{Mse}}{\mathrm{r}}$

Phenotypic variance $\sigma^{2} p=\sigma^{2} g+\sigma^{2} e$

Where, $\sigma^{2} \mathrm{~g}$ - Genotypic variance; MSg - Mean square of genotype; MSe - Mean square of error; $\sigma^{2} I$ - Interaction variance; MSI - Mean square of interaction variance; $\sigma^{2} p-$ phenotypic variance; $\sigma^{2} \mathrm{e}-$ Error variance; $r$ - Number of replication and 1 - Number of locations.

Model of the experiment: The ANOVA for individual location followed the following model:

$$
\mathrm{P}_{\mathrm{ijk}}=\mu+\mathrm{g}_{\mathrm{i}}+\mathrm{b}_{\mathrm{k}(\mathrm{j})}+\mathrm{r}_{\mathrm{j}}+\mathrm{e}_{\mathrm{ijk}}
$$

Where, $P_{i j k}=$ phenotypic value of $i^{\text {th }}$ genotype under $j^{\text {th }}$ replication and $\mathrm{k}^{\text {th }}$ incomplete block within replication $\mathrm{j}$; $\mu=$ grand mean; $G_{i}=$ the effect of $i^{\text {th }}$ genotype; $B_{k(j)}=$ the effect of incomplete block $k$ within replication $j ; R_{j}=$ the effect of replication $\mathrm{j}$; and $\mathrm{E}_{\mathrm{ijk}}=$ the residual or effect of random error.

For combined analysis of variance over locations, the total variations among the inbred lines measured using the following model:

$$
\mathrm{P}_{\mathrm{ijkz}}=\mu+\mathrm{G}_{\mathrm{i}}+\mathrm{B}_{\mathrm{k}(\mathrm{j})(\mathrm{z})}+\mathrm{R}_{\mathrm{j}(\mathrm{z})}+\mathrm{L}_{\mathrm{z}}+(\mathrm{GL})_{\mathrm{iz}}+\mathrm{E}_{\mathrm{ijkz}}
$$

Where, $P_{i j k z}=$ phenotypic value of $i^{\text {th }}$ genotype under $j^{\text {th }}$ replication at $\mathrm{z}^{\text {th }}$ location and $\mathrm{k}^{\text {th }}$ incomplete block within replication $\mathrm{j}$ and location $\mathrm{z} ; \mu=$ grand mean; $\mathrm{Gi}=$ the effect of ith genotype; $\operatorname{Bk}(\mathrm{j})(\mathrm{z})=$ the effect of incomplete block $\mathrm{k}$

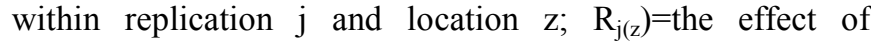
replication $\mathrm{j}$ within location $\mathrm{z} ; \mathrm{L}_{\mathrm{z}}=$ the effect of location $\mathrm{z}$; $(\mathrm{GL})_{\mathrm{iz}}=$ the interaction effects between genotype and location; and Eijkz= the residual or effect of random error.

Table 3. Anova skeleton for individual locations (HARC and DZARC) in simple lattice design.

\begin{tabular}{lll}
\hline Source of variation & Degree of freedom & Sum of Squares (SS) \\
\hline Replications (r) & $\mathrm{r}-1$ & $\mathrm{SSr}$ \\
Genotypes (g un djusted) & $\mathrm{g}-1$ & $\mathrm{SSg}$ \\
Block in rep (adjusted) & $\mathrm{r}(\mathrm{b}-1)$ & $\mathrm{SSB}$ \\
Intra block error & $(\mathrm{b}-1)(\mathrm{rb}-\mathrm{b}-1)$ & $\mathrm{SSE}$ \\
Total $(\mathrm{T})$ & $\mathrm{rb}-1$ & $\mathrm{SST}$ \\
\hline
\end{tabular}

Where; $g=$ Number of genotypes, $\mathrm{b}=$ Number of plots in a block or block size $/$ intra block, $* \mathrm{E}_{\mathrm{b}}-$ Error for block $=\mathrm{SSB} / \mathrm{r}(\mathrm{b}-1)$ and $\mathrm{E}_{\mathrm{e}}-\mathrm{Experimental}$ error $=$ $\mathrm{SSE} /((\mathrm{b}-1)(\mathrm{rb}-\mathrm{b}-1))$.

Table 4. Analysis of variances for combined over locations in simple lattice design.

\begin{tabular}{llll}
\hline Source of variation & Degree of freedom & Mean square (MS) & Expected mean square (EMS) \\
\hline Location (L) & $\mathrm{L}-1$ & $\mathrm{MSL}$ & $\sigma^{2} \mathrm{e}+\mathrm{r} \sigma^{2} \mathrm{gi}+\mathrm{g} \sigma^{2} \mathrm{~L}$ \\
Replication with in location(r) & $\mathrm{L}(\mathrm{r}-1)$ & $\mathrm{MSr}$ & $\sigma^{2} \mathrm{e}+\mathrm{g} \sigma^{2} \mathrm{rL}$ \\
Blocks within replication(b) & $\mathrm{r}(\mathrm{b}-1)$ & $\mathrm{MSb}$ & $\sigma^{2} \mathrm{e}+\mathrm{r} \sigma^{2} \mathrm{gi}+\mathrm{r} \sigma^{2} \mathrm{~g}$ \\
Genotypes (g) & $\mathrm{g}-1$ & $\mathrm{MSg}$ & $\sigma^{2} \mathrm{e}+\mathrm{r} \sigma^{2} \mathrm{gi}+\mathrm{rL} \sigma^{2} \mathrm{~g}$ \\
$\mathrm{~g}$ x L interaction (i) & $(\mathrm{g}-1)(\mathrm{L}-1)$ & $\mathrm{MSi}$ & $\sigma^{2} \mathrm{e}+\mathrm{r} \sigma^{2} \mathrm{gi}$ \\
Error (e) & $\mathrm{Lg}(\mathrm{r}-1)-(\mathrm{rb}-1)$ & $\mathrm{MSe}$ & $\sigma^{2} \mathrm{e}$ \\
\hline
\end{tabular}

Where, b- represent intra blocks; $\sigma^{2} \mathrm{~g}=$ genotypic variance, $\sigma^{2} \mathrm{e}=$ environmental variance, $\sigma^{2} \mathrm{~L}=$ location variance, $\sigma^{2} \mathrm{r}=$ replication variance, and $\sigma^{2}$ gi $=$ genotype $\mathrm{x}$ location interaction variance, $\mathrm{L}=$ number of locations, $\mathrm{g}=$ number of genotypes and $\mathrm{r}=$ number of replications. Appropriate mean separation will be done if there is significance.

Comparing $\mathrm{E}_{\mathrm{b}}$ with $\mathrm{E}_{\mathrm{e}}$ : - If $\mathrm{E}_{\mathrm{b}} \leq \mathrm{E}_{\mathrm{e}}$, Adjustment of treatment means will have no effect and analyze as if it were an RCBD using replications as blocks.

If $E_{b}>E_{e}$ then compute an adjustment factor $A$.

$A=\left(E_{b}-E_{e}\right) /(b(r-1) E b)$, used to compute adjusted treatment means.

Relative Efficiency: - Estimate the error mean square of an $\mathrm{RCBD} \mathrm{E}_{\mathrm{RCBD}}=(\mathrm{SSB}+\mathrm{SSE}) /((\mathrm{g}-1)(\mathrm{r}-1))$, Then the relative efficiency of the lattice is $\mathrm{RE}=\mathrm{E}_{\mathrm{RCBD}} / \mathrm{E}_{\mathrm{e}}$.

From the analysis of variances of data from each locations efficiency of simple lattice design over RCBD was calculated depending on the above formula and simple lattice have $26.2 \%$ efficient than randomized complete block design (RCBD).

\subsubsection{Estimation of Variance Components}

Phenotypic (PCV) and genotypic (GCV) coefficients of variation were calculated according to the method suggested by Burton [40] as:

Phenotypic Coefficient of Variation: 


$$
\operatorname{PCV}=\left[\frac{\sqrt{\delta^{2} p}}{\mu}\right] \times 100
$$

Where; $\mathrm{PCV}=$ phenotypic coefficient of variation; $\mu=$ Population mean.

Genetic coefficient of Variation:

$$
\mathrm{GCV}=\left[\frac{\sqrt{\delta^{2} g}}{\mu}\right] \times 100
$$

Where; GCV $=$ phenotypic coefficient of variation; $\mu=$ Population mean PCV and GCV values $>20 \%$ is regarded as high, $10-20 \%$ is considered as medium and $<10 \%$ is considered as low [41].

\subsubsection{Estimates of Broad Sense Heritability}

Heritability in broad sense $\left(\mathrm{H}^{2}\right)=\frac{\sigma^{2} g}{\sigma^{2} p} \times 100 \%$; According to Allard [42] Where, $\sigma^{2} g$ and $\sigma^{2} p$ are genetic and phenotypic variance.

According to Robinson [43], broad sense heritability in cultivated plants can be categorize into low for values of 0 $30 \%$, medium for estimates of $30-60 \%$, and high for values above $60 \%$.

\subsubsection{Estimates of Genetic Advance}

Genetic Advance (GA) was estimated using the formula of Johnson [44] as follows. GA $=\mathrm{H}^{2} \mathrm{k}^{*} \sigma \mathrm{p}$ Where, GA = Genetic advance, $\mathrm{H}^{2}$ is broad sense heritability, $\mathrm{k}(=2.056)$ was the selection differential expressed in phenotypic standard deviation depending on the selection intensity of $5 \%, \sigma \mathrm{p}$ is the phenotypic standard deviation.

Genetic advance as percent of mean (GAM) also calculated as follows according to Falconer and Mackay [45]:

$$
\mathrm{GAM}=\frac{\mathrm{GA}}{\text { Mean }} \times 100 \%,
$$

Where $0-10 \%$ is low, $10-20 \%$ is moderate and $20 \%$ and above is high.

\section{Results and Discussions}

\subsection{Mean Performance}

Mean squares of the 16 traits from analysis of variance (ANOVA) at individual location and combined over the two locations are presented in Tables 5, 6 and 7. From the separate analysis, at Holetta highly significant differences among inbred lines $(p<0.01)$ were observed for all traits except number of fertile tillers per plant. At Debre Zeit, significant differences among lines $(p<0.01)$ were observed for all traits except peduncle length, second culm internode length, Second culm internode diameter, number of branches per panicle and fertile tillers per plant.

For some traits like grain yield, harvest index, lodging index, days to heading and maturity lower mean values were recorded at Debre Zeit and higher values recorded at Holetta. In the case of remaining traits such as plant height, panicle length, culm length, second culm internode length, second culm internode diameter, number of fertile tillers, number of branches and number of spikelets per panicle the highest value recorded at Debre Zeit whereas the lowest value at Holetta. This indicates that the locations had significant effects on the performance of semi-dwarf tef recombinant inbred lines (Tables 5 and 6). This expected based on the distinct agro-climatic classification of the test

\begin{tabular}{|c|c|c|c|c|c|c|c|}
\hline Traits & $\operatorname{Rep}(\mathbf{d f}=1)$ & Intra blocks $(\mathrm{df}=12)$ & Inbred lines $(\mathrm{df}=48)$ & Error $(d f=36)$ & CV $(\%)$ & Mean & $\mathbf{R}^{2}$ \\
\hline DH & $16.33 * *$ & $3.85 \mathrm{~ns}$ & $35.19 * *$ & 2.29 & 2.49 & 60.69 & 96.04 \\
\hline DM & $1489.02 * *$ & $74.53 * *$ & $68.55 * *$ & 15.16 & 3.25 & 119.94 & 92.53 \\
\hline GFP & $1193.51 * *$ & $80.26^{* *}$ & $58.46^{* *}$ & 13.31 & 6.16 & 59.24 & 92.64 \\
\hline PH & $18.17 \mathrm{~ns}$ & $125.85 * *$ & $186.06^{* *}$ & 9.98 & 3.52 & 89.76 & 96.73 \\
\hline PL & $19.39 *$ & $7.34 *$ & $35.10 * *$ & 3.22 & 5.59 & 32.09 & 94.23 \\
\hline $\mathrm{CL}$ & $0.02 \mathrm{~ns}$ & $75.35 * *$ & $87.20 * *$ & 6.56 & 4.44 & 57.68 & 95.70 \\
\hline PDL & $6.99 \mathrm{~ns}$ & $3.18 \mathrm{~ns}$ & $12.97 * *$ & 2.32 & 6.50 & 23.41 & 90.00 \\
\hline SCIL & $1.69 \mathrm{~ns}$ & $4.07 * *$ & $4.09 * *$ & 0.74 & 10.00 & 8.61 & 90.00 \\
\hline SCID & $0.06 \mathrm{~ns}$ & $0.04 \mathrm{~ns}$ & $0.05 * *$ & 0.02 & 8.32 & 1.78 & 76.26 \\
\hline NFT & $0.06 \mathrm{~ns}$ & $0.86 \mathrm{~ns}$ & $0.62 \mathrm{~ns}$ & 0.73 & 25.91 & 3.29 & 61.81 \\
\hline NBP & $12.93 \mathrm{~ns}$ & $7.62 \mathrm{~ns}$ & $11.77 * *$ & 5.16 & 8.77 & 25.89 & 80.99 \\
\hline NSP & $318.24 \mathrm{~ns}$ & $3976.57 \mathrm{~ns}$ & $8016.64 * *$ & 2371.36 & 11.24 & 433.21 & 84.02 \\
\hline $\mathrm{ABM}$ & $344680.1 \mathrm{~ns}$ & $2295049.5 * *$ & $2586895.7 * *$ & 281746.60 & 9.26 & 5733.10 & 95.85 \\
\hline GY & $251709.31 * *$ & $317362.28 * *$ & $158861.96 * *$ & 40207.54 & 12.57 & 1595.56 & 93.58 \\
\hline HI & $20.88 \mathrm{~ns}$ & $16.20 \mathrm{~ns}$ & $34.37 * *$ & 12.86 & 12.77 & 28.09 & 81.91 \\
\hline LI & $35.52 \mathrm{~ns}$ & $9.53 \mathrm{~ns}$ & $48.56 * *$ & 12.46 & 5.54 & 63.72 & 88.93 \\
\hline
\end{tabular}
locations [46].

Table 5. Analysis of variance for the 16 traits of 49 semi-dwarf tef recombinant inbred lines evaluated at Holetta.

Where; ${ }^{*}, * *$ Significant at $\mathrm{p} \leq 0.05$ and $\mathrm{p} \leq 0.01$ respectively, while ns- non-significant, $\mathrm{DH}=$ days to heading, DM $=$ days to maturity, GFP $=$ grain filling period, $\mathrm{PH}=$ plant height, $\mathrm{PL}=$ panicle length, $\mathrm{CL}=$ culm length, $\mathrm{PDL}=$ peduncle length, $\mathrm{SCIL}=\mathrm{second}$ culm internode length, $\mathrm{SCID}=$ second basal culm internode diameter, $\mathrm{NFT}=$ no. of fertile tillers per plant, $\mathrm{NBP}=$ no. of branches per panicle, $\mathrm{NSP}=$ no. of spikelets per panicle, $\mathrm{ABM}=$ above ground biomass yield $(\mathrm{kg} / \mathrm{ha}), \mathrm{GY}=$ grain yield $(\mathrm{Kg} / \mathrm{ha}), \mathrm{HI}=$ harvest index, $\mathrm{LI}=$ lodging index, $\mathrm{df}=$ degree of freedom and $\mathrm{CV}=$ coefficient of variation $(\%)$. 
Table 6. Analysis of variance for the 16 traits of 49 tef recombinant inbred lines evaluated at Debre Zeit.

\begin{tabular}{|c|c|c|c|c|c|c|c|}
\hline Traits & $\operatorname{Rep}(d f=1)$ & Intra-blocks $(\mathrm{df}=12)$ & Inbred lines $(\mathrm{df}=48)$ & Error $(d f=36)$ & CV (\%) & MEAN & $\mathbf{R}^{2}$ \\
\hline $\mathrm{DH}$ & $5.39 \mathrm{~ns}$ & $9.03 \mathrm{~ns}$ & $16.67 * *$ & 6.99 & 5.55 & 92.74 & 79.71 \\
\hline DM & $0.83 \mathrm{~ns}$ & $9.19 *$ & $16.56 * *$ & 4.34 & 2.25 & 45.06 & 86.64 \\
\hline GFP & $10.45 \mathrm{~ns}$ & $10.74 \mathrm{~ns}$ & $25.25 * *$ & 11.24 & 7.44 & 102.79 & 79.66 \\
\hline $\mathrm{PH}$ & $34.33 \mathrm{~ns}$ & $24.84 \mathrm{~ns}$ & $127.72 * *$ & 23.79 & 4.74 & 39.91 & 90.30 \\
\hline PL & $19.39 \mathrm{~ns}$ & $4.48 \mathrm{~ns}$ & $18.54 *$ & 9.57 & 7.75 & 62.89 & 74.75 \\
\hline CL & $2.12 \mathrm{~ns}$ & $36.84 \mathrm{~ns}$ & $88.09 * *$ & 34.40 & 9.33 & 22.81 & 82.21 \\
\hline PDL & $28.88 *$ & $7.06 \mathrm{~ns}$ & $5.66 \mathrm{~ns}$ & 6.14 & 10.86 & 12.2 & 67.74 \\
\hline SCIL & $9.43 *$ & $4.62 * *$ & $2.08 \mathrm{~ns}$ & 1.78 & 10.93 & 1.83 & 74.01 \\
\hline SCID & $0.06 \mathrm{~ns}$ & $0.02 \mathrm{~ns}$ & $0.03 \mathrm{~ns}$ & 0.03 & 8.74 & 6.93 & 64.16 \\
\hline NFT & $5.49 *$ & $1.40 \mathrm{~ns}$ & $0.74 \mathrm{~ns}$ & 0.90 & 17.35 & 25.69 & 65.10 \\
\hline NBP & $1.30 \mathrm{~ns}$ & $7.44 \mathrm{~ns}$ & $7.97 \mathrm{~ns}$ & 6.71 & 10.08 & 453.35 & 66.20 \\
\hline NSP & $9035.52 *$ & $4254.33 *$ & $16735.10 * *$ & 2169.42 & 10.27 & 4.32 & 92.38 \\
\hline $\mathrm{ABM}$ & $3594830.4 * *$ & $661930 \mathrm{~ns}$ & $6456901.7^{* *}$ & 380149.40 & 7.96 & 1534.61 & 96.20 \\
\hline GY & $186602.9 * *$ & $25269.68 \mathrm{~ns}$ & $446728.35 * *$ & 14970.99 & 7.97 & 19.85 & 97.83 \\
\hline HI & $4.67 \mathrm{~ns}$ & $5.44 \mathrm{~ns}$ & $21.12 * *$ & 4.43 & 10.61 & 3403.12 & 88.37 \\
\hline LI & $0.09 \mathrm{~ns}$ & $64.83 *$ & $158.46^{* *}$ & 32.70 & 9.70 & 47.68 & 88.81 \\
\hline
\end{tabular}

Where; $* * *$ Significant at $\mathrm{p} \leq 0.05$ and $\mathrm{p} \leq 0.01$ respectively, while ns- non-significant, $\mathrm{DH}=$ days to heading, $\mathrm{DM}=$ days to maturity, GFP $=$ grain filling period, $\mathrm{PH}=$ plant height, $\mathrm{PL}=$ panicle length, $\mathrm{CL}=$ culm length, $\mathrm{PDL}=$ peduncle length, $\mathrm{SCIL}=\mathrm{second}$ culm internode length, $\mathrm{SCID}=\mathrm{second}$ basal culm internode diameter, $\mathrm{NFT}=$ no. of fertile tillers per plant, $\mathrm{NBP}=$ no. of branches per panicle, $\mathrm{NSP}=$ no. of spikelets per panicle, $\mathrm{ABM}=$ above ground biomass yield $(\mathrm{kg} / \mathrm{ha}), \mathrm{GY}=$ grain yield $(\mathrm{Kg} / \mathrm{ha}), \mathrm{HI}=$ harvest index, $\mathrm{LI}=$ lodging index, $\mathrm{df}=$ degree of freedom and $\mathrm{CV}=$ coefficient of variation $(\%)$.

Table 7. Analysis of variance for 16 traits of 49 semi-dwarf tef recombinant inbred lines over the two locations.

\begin{tabular}{|c|c|c|c|c|c|c|c|c|}
\hline Traits & $\begin{array}{l}\text { Locations }(\mathrm{L}) \\
(\mathrm{df}=1)\end{array}$ & $\begin{array}{l}\text { Replications (r) } \\
(\mathrm{df}=1)\end{array}$ & $\begin{array}{l}\text { Intra Block (b) } \\
(\mathrm{df}=12)\end{array}$ & $\begin{array}{l}\text { Inbred lines (I) } \\
(\mathrm{df}=48)\end{array}$ & I $\times L(d f=48)$ & $\begin{array}{l}\text { Error (e) } \\
(\mathrm{df}=85)\end{array}$ & $\begin{array}{l}\text { CV } \\
(\%)\end{array}$ & $\mathbf{R}^{2}$ \\
\hline $\mathrm{DH}$ & $8294.01 * *$ & $1.47 \mathrm{~ns}$ & $9.22 *$ & $42.09 * *$ & $11.83 * *$ & 4.69 & 4.00 & 96.57 \\
\hline DM & $36235.84 * *$ & $780.01 * *$ & $59.95 * *$ & $54.80 * *$ & $38.75 * *$ & 19.96 & 4.20 & 96.20 \\
\hline GFP & $9857.65 * *$ & $713.65 * *$ & $63.37 * *$ & $56.21 * *$ & $39.14 * *$ & 20.07 & 8.59 & 90.71 \\
\hline PH & $8320.05 * *$ & $51.22 \mathrm{~ns}$ & $63.36 * *$ & $267.03 * *$ & $50.21 * *$ & 26.64 & 5.36 & 91.95 \\
\hline PL & $2996.78 * *$ & $38.80 * *$ & $7.44 \mathrm{~ns}$ & $44.67 * *$ & $8.92 *$ & 6.04 & 6.83 & 91.96 \\
\hline CL & $1330.17 * *$ & $0.86 \mathrm{~ns}$ & $44.40 \mathrm{~ns}$ & $134.06 * *$ & $46.59 * *$ & 26.93 & 8.61 & 83.40 \\
\hline PDL & $17.34 *$ & $32.15 * *$ & $5.79 \mathrm{~ns}$ & $13.12 * *$ & $5.79 \mathrm{~ns}$ & 4.25 & 8.92 & 76.48 \\
\hline SCIL & $631.52 * *$ & $1.57 \mathrm{~ns}$ & $4.49 * *$ & $3.99 * *$ & $2.18 \mathrm{~ns}$ & 1.77 & 12.79 & 86.85 \\
\hline SCID & $0.17 * *$ & $0.04 \mathrm{~ns}$ & $0.04 *$ & $0.06^{* *}$ & $0.02 \mathrm{~ns}$ & 0.02 & 8.31 & 68.44 \\
\hline NFT & $231.04 * *$ & $2.21 \mathrm{~ns}$ & $1.24 \mathrm{~ns}$ & $0.77 \mathrm{~ns}$ & $0.69 \mathrm{~ns}$ & 0.87 & 21.33 & 81.09 \\
\hline NBP & $1.90 \mathrm{~ns}$ & $11.22 \mathrm{~ns}$ & $11.90 *$ & $10.60 * *$ & $10.50 * *$ & 5.51 & 9.10 & 72.36 \\
\hline NSP & $19872.94 * *$ & $6372.6 \mathrm{~ns}$ & $4382.45 \mathrm{~ns}$ & $13649.28 * *$ & $12226.54 * *$ & 2501.54 & 11.28 & 86.54 \\
\hline $\mathrm{ABM}$ & $197799029 * *$ & $3082888.8 * *$ & $1531599.9 * *$ & $6604503.8 * *$ & $3131395.8 * *$ & 491640.4 & 10.41 & 94.79 \\
\hline GY & $182640.23 *$ & $435881.02 * *$ & $159891.98 * *$ & $358714.8 * *$ & $322262.61 * *$ & 49196.92 & 14.17 & 91.21 \\
\hline HI & $3330.69 * *$ & $22.65 \mathrm{~ns}$ & $6.88 \mathrm{~ns}$ & $26.19 * *$ & $34.37 * *$ & 9.44 & 12.82 & 85.95 \\
\hline LI & $1098.45 * *$ & $19.61 \mathrm{~ns}$ & $42.03 \mathrm{~ns}$ & $130.43 * *$ & $94.53 * *$ & 23.88 & 7.96 & 87.05 \\
\hline
\end{tabular}

Where; $* * *$ Significant at $\mathrm{p} \leq 0.05$ and $\mathrm{p} \leq 0.01$ respectively, while ns- non-significant, $\mathrm{DH}=$ days to heading, $\mathrm{DM}=$ days to maturity, GFP $=$ grain filling period, $\mathrm{PH}=$ plant height, $\mathrm{PL}=$ panicle length, $\mathrm{CL}=$ culm length, $\mathrm{PDL}=$ peduncle length, $\mathrm{SCIL}=$ second culm internode length, $\mathrm{SCID}=$ second basal culm internode diameter, $\mathrm{NFT}=$ no. of fertile tillers per plant, $\mathrm{NBP}=$ no. of branches per panicle, $\mathrm{NSP}=$ no. of spikelets per panicle, $\mathrm{ABM}=$ above ground biomass yield $(\mathrm{kg} / \mathrm{ha}), \mathrm{GY}=$ grain yield $(\mathrm{Kg} / \mathrm{ha}), \mathrm{HI}=$ harvest index, $\mathrm{LI}=$ lodging index, $\mathrm{df}=$ degree of freedom and $\mathrm{CV}=$ coefficient of variation $(\%)$.

The combined analysis of variance over the two locations of the 49 semi-dwarf tef recombinant inbred lines showed highly significant $(\mathrm{P}<0.01)$ genotype effects for all 16 traits, except for number of fertile tillers per plant (Table 7). Locations revealed highly significant $(\mathrm{P} \leq 0.01)$ effects on 13 of the traits and significant $(\mathrm{P} \leq 0.05)$ effects on two traits (peduncle length and grain yield), while number of branches per main panicle was not significantly affected by locations. Genotype and locations interacted highly significantly on eleven of the traits, while one trait (panicle length) showed significant interaction and four traits (peduncle length, second culm internode length, second culm internode diameter and number of fertile tillers showed no statically significant interaction effects. This indicate that the two location environmental conditions highly different.
Comparisons of the mean performances of each trait of combined locations presented on (Appendix Table 9). From grain yield traits RIL-14, RIL-45, RIL-28 and RIL-41 in this order had mean grain yields of 2.52, 2.29, 2.21 and $2.19 \mathrm{tha}^{-1}$, which were higher than that of the standard check Boset $\left(1.83 \mathrm{tha}^{-1}\right)$ and the local check $\left(2.14 \mathrm{t} \mathrm{ha}^{-1}\right)$. This indicates that grain yield potential of these semi-dwarf tef were different; thus, indicating that the opportunity for breeders to further improvement of tef yield through the existing breeding strategy. In line with the present findings, Yifru and Hailu [15] also reported the grain yield potential in tef improvement.

In lodging index traits RIL-19 (39.5\%), RIL-75 (44.5\%), RIL-8 (47.0\%), RIL-169 (50.5\%), RIL-22 (51.1\%), RIL-14 (54.0\%) and DZ-01-192 (53.0\%) have the least lodging index than local and standard checks as well as the parent checks 
except RIL-14, which more than DZ-01-192 parental check by one percent. This indicate that there is high potential to increase grain yield by decreasing the loss exposed by lodging. From the main lodging related traits second basal culm internode diameter have the highest mean performance for the following recombinant inbred lines such as RIL- 169 (2.13 mm), RIL- 14 (2.08 mm), RIL-57 (1.96), RIL-45 (92 $\mathrm{mm})$, RIL-175 (1.91 mm) and parental check (DZ-01-192) which have $1.98 \mathrm{~mm}$, while the standard and local checks shown lower in diameter. As indicated above the highest in grain yield have highest culm diameter and lower lodging index, this finding in line with Habte [31].

This indicate that as the second basal internode diameter increases the lodging become decrease and grain yield increase even if the other traits may averagely affect their association non -significant in this study. RIL- $14(115.95 \mathrm{~cm})$ also exhibited the longest plant height and length of the culm, panicle and second basal culm in addition to culm diameter, next to RIL-169, which have highest diameter. However, the parental line DZ-01-192 also had the longest better than the checks. Generally, all the recombinant inbred lines have shown clearly different mean performance in each traits comparing with each other and checks (Appendix Table 9).

Relative efficiency of the simple lattice design compare to that of a randomized complete block design where done as follows:

First by computing MSE for the RCBD as:

$$
\mathrm{E}_{\mathrm{RCBD}}=(\mathrm{SSB}+\mathrm{SSE}) /\left(\mathrm{k}^{2}-1\right)(\mathrm{r}-1) \text {. }
$$

Then

$$
\% \text { relative efficiency }=\left(E_{\mathrm{RCBD}} / \mathrm{E}_{\mathrm{e}}{ }^{\prime}\right) 100
$$

while,

$$
\mathrm{Ee}^{\prime}=(1+(\mathrm{rkA}) /(\mathrm{k}+1)) \mathrm{Ee}
$$

and

$$
A=\left(E_{b}-E_{e}\right) /\left(k(r-1) E_{b}\right) .
$$

where $\mathrm{E}_{\mathrm{e}^{-}}^{\prime}$ effective error mean square, A- adjusted treatment, $\mathrm{k}^{2}$ - number of treatments, $\mathrm{k}$ - number of plots in block, $r$ - number of replications, $E_{e}=$ pooled error and $E_{b^{-}}$ block error.

Therefore, there is a $26.2 \%$ gain in efficiency from using the lattice as this study.

\subsection{Genotypic and Phenotypic Coefficients of Variation}

The value of genotypic coefficients of variation (GCV) and phenotypic coefficients of variation (PCV) were grouped to High $>20 \%$, intermediate $10-20 \%$ and low $<10 \%$ [41]. Depending on this for the current study, the GCV ranged from $0.61 \%$ for number of branches per panicle to $13.83 \%$ for above ground biomass. All traits grouped in the low GCV value except above ground biomass, which grouped under the intermediate GCV value (Table 8). Similarly, Solomon [29] reported that plant height, days to maturity and harvest index had low GCV values. Correspondingly, Habtamu [5] and Habte [32] also reported that days to maturity and days to grain filling had low GCV values, respectively. This might be attributing to high influence of the environment on the inbred lines. Low values of GCV suggest less scope of improvement for these traits by selection. The magnitude of genetic variation better assessed from genotypic coefficients of variation [30]. Therefore, selecting the tef recombinant inbred lines having higher harvest index and lower lodging index could help enhancing the productivity of tef.

PCV values ranged from $4.55 \%$ for days to maturity to $26.36 \%$ for grain yield (Table 8 ). The grain yield and above ground biomass were categorized into high PCV $(>20 \%)$. However, panicle length, culm length, second basal culm internode length, number of spikelets per main panicle, harvest index and lodging index were grouped into intermediate PCV values $(10-20 \%)$. The third group of PCV had a low (0-10\%) value, which computed for days to heading days to maturity, grain filling period, plant height, peduncle length and second basal culm internode diameter and number of branches per main panicle. PCV is usually the reflection of the effects of inbred lines and environment. If the PCV is greater than GCV it means the environment contributes more than the genes' effect for phenotypic expression of the trait. Previous findings by different researchers were also similar to the present study results $[22,5,32]$.

\subsection{Heritability}

The broad sense heritability $\left(\mathrm{H}^{2}\right)$ ranged from $68.35 \%$ for plant height to $0.47 \%$ for number of branches per main panicle (Table 8). In addition to plant height, panicle length $(66.71 \%)$ also had high heritability values $>60 \%$ [43]. This indicates less influence of environment as compared to the genetic factors in controlling the traits and it suggested that the progenies would have a higher chance to perform the same as the parent. Days to heading, culm length, peduncle length, second basal culm internode length, second basal culm internode diameter, above ground biomass had estimates categorized under moderate heritability $(30<60 \%)$.

Whereas days to maturity, grain filling period, number of branches per main panicle, number of spikelets per main panicle, grain yield, harvest index and lodging index categorized into low heritability values $(<30 \%)$. Low heritability indicates the non- predictable of the phenotype range of environments. This showed that these traits are highly influenced by environment. This suggestion is supported with the findings of several authors who conducted studies on tef $[48,21,29,5,47,32]$.

\subsection{Expected Genetic Advance}

The expected genetic advance (GA), expressed as a percentage of the mean, ranged from $0.09 \%$ for number of branches to $17.02 \%$ for above ground biomass (Table 8). Similarly, moderate expected GA observed for plant height $(13.02 \%)$ and panicle length (13.97\%) and culm length $(11.12 \%)$. All the rest of the traits showed low genetic 
advance values as a percentage of mean between $0.09 \%$ and $8.05 \%$. Similar findings with this study also reported by Abel $[47,21,29]$.

Low heritability and genetic advance estimated for the traits suggest that breeding for those traits would be a difficult task. Johnson [44] in soybean suggested that heritability estimate with genetic gain are more useful for effective improvement. In addition to high heritability along with high genetic advance as percentage of mean implies the role of additive genes for the expression of the characters, and thus it could be very effective in improvement upon selection. In general, high GCV, heritability and genetic advances for traits could be an excellent tool for improving through selection of high performing genotypes. In the current study even if no high GCV recorded, high heritability (plant height and panicle length) and high above ground biomass genetic advance were displayed as also as reported by Chekole [49].

Table 8. Phenotypic and Genotypic coefficients of variation, Heritability, Genetic advance and Genetic advance as percent of means for 15 traits in 49 recombinant inbred lines of semi-dwarf tef at Holetta and Debre Zeit.

\begin{tabular}{|c|c|c|c|c|c|c|c|c|c|}
\hline Traits & $\sigma^{2} g$ & $\sigma^{2} \mathrm{e}$ & $\sigma^{2} g l$ & $\sigma^{2} p$ & GCV & PCV & $\mathbf{H}^{2}$ & GA & GAM \\
\hline $\mathrm{DH}$ & 7.57 & 2.34 & 3.57 & 13.48 & 5.08 & 6.78 & 56.12 & 4.24 & 7.83 \\
\hline DM & 4.01 & 9.98 & 9.40 & 23.39 & 1.88 & 4.55 & 17.16 & 1.71 & 1.61 \\
\hline GFP & 4.27 & 10.04 & 9.54 & 23.84 & 3.96 & 9.36 & 17.90 & 1.80 & 3.45 \\
\hline PH & 54.21 & 13.32 & 11.79 & 79.31 & 7.65 & 9.25 & 68.35 & 12.54 & 13.02 \\
\hline PL & 8.94 & 3.02 & 1.44 & 13.40 & 8.30 & 10.17 & 66.71 & 5.03 & 13.97 \\
\hline $\mathrm{CL}$ & 21.87 & 13.47 & 9.83 & 45.16 & 7.76 & 11.15 & 48.42 & 6.70 & 11.12 \\
\hline PDL & 1.83 & 2.13 & 0.77 & 4.73 & 5.86 & 9.41 & 38.76 & 1.74 & 7.51 \\
\hline SCIL & 0.45 & 0.89 & 0.20 & 1.54 & 6.47 & 11.94 & 29.34 & 0.75 & 7.22 \\
\hline SCID & 0.01 & 0.01 & 0.001 & 0.02 & 5.52 & 7.81 & 50.00 & 0.15 & 8.05 \\
\hline NBP & 0.02 & 2.75 & 2.50 & 5.28 & 0.61 & 8.88 & 0.47 & 0.02 & 0.09 \\
\hline NSP & 355.69 & 1250.77 & 4862.50 & 6468.96 & 4.25 & 18.14 & 5.50 & 9.11 & 2.06 \\
\hline $\mathrm{ABM}$ & 868277.00 & 245820.20 & 1319877.70 & 2433974.90 & 13.83 & 23.16 & 35.67 & 1146.48 & 17.02 \\
\hline GY & 9113.06 & 24598.46 & 136532.85 & 170244.36 & 6.10 & 26.36 & 5.35 & 45.50 & 2.91 \\
\hline HI & 2.05 & 4.72 & 12.46 & 19.23 & 5.97 & 18.29 & 10.63 & 0.96 & 4.01 \\
\hline LI & 8.98 & 11.94 & 35.33 & 56.24 & 4.88 & 12.22 & 15.96 & 2.47 & 4.02 \\
\hline
\end{tabular}

Where; $\sigma^{2}$ g- genotypic variance, $\sigma^{2}$ - environmental variance, $\sigma^{2}$ gl- Genotypic by location interaction variance, $\sigma^{2} p$ - phenotypic variance $(\mathrm{GCV}$ - genotypic coefficients of variation (\%), PCV-phenotypic coefficients of variation (\%), $\mathrm{H}^{2}$ - Broad sense heritability (\%), GA - genetic advance and GAM- Genetic advances as percent of means $(\%) . \mathrm{DH}=$ days to heading, $\mathrm{DM}=$ days to maturity, $\mathrm{GFP}=$ grain filling period, $\mathrm{PH}=\mathrm{plant}$ height, $\mathrm{PL}=$ panicle length, $\mathrm{CL}=\mathrm{culm}$ length, $\mathrm{PDL}=$ peduncle length, $\mathrm{SCIL}=$ second culm internode length, $\mathrm{SCID}=$ second culm internode diameter, $\mathrm{NBP}=$ no of branches per panicle, $\mathrm{NSP}=$ no. of spikelets per panicle, $\mathrm{ABM}=$ above ground biomass $(\mathrm{kg} / \mathrm{ha}), \mathrm{GY}=$ grain yield $(\mathrm{kg} / \mathrm{ha}), \mathrm{HI}=$ harvest index, $\mathrm{LI}=\mathrm{lodging}$ index.

\section{Conclusion}

The current experiment carried out on 49 semi-dwarf tef recombinant inbred lines that selected from GA-10-3 X DZ01-192 crosses of $F_{7}$ single seed descent developed inbred lines at Debre Zeit center. The results of this study indicate that highly significant difference among the recombinant inbred lines for all traits evaluated except for number of fertile tillers per plant. Genotypes by locations interactions were highly significant for 10 traits.

Grain yield showed the maximum phenotypic coefficient of variation $(26.36 \%)$ followed by above ground biomass $(23.16 \%)$, while moderate phenotypic coefficient of variation $(20>10 \%)$ estimates were recorded for number of spikelets per main panicle, harvest index, lodging index, second culm internode length, culm length and panicle length. The remaining traits showed low phenotypic coefficient of variation values. Moderate genotypic coefficient of variation (10-20\%) was recorded for above ground biomass while, genotypic coefficient of variation was low for the rest of the traits.

Two of the traits (i.e. plant height and panicle length) showed high heritability ( $>60 \%$ ), while days to heading, culm length, peduncle length, second culm internode diameter, second culm internode length and above ground biomass showed intermediate heritability estimates. The remaining traits showed low heritability $(<30 \%)$. Genetic advance as percentage of mean were maximum for above ground biomass $(>17.02 \%)$ and lower for number of branches per panicle $(0.09 \%)$.

Generally, genetic variation has supreme importance to the breeders, as it is prerequisite for any improvement in crop plants and identification of superior recombinant inbred lines. This study also revealed that four recombinant inbred lines from the studied recombinant inbred lines had higher yield than local and standard checks. There were differences in the performance of the recombinant inbred lines as there were statistically significant differences among recombinant inbred lines for most of the traits studied over the locations.

However, the level of genetic variations for many traits including grain yield might be not sufficient to expect progress in selection and showed moderate to low genetic coefficient of variation that made improvement through selection a difficult task. Aboveground biomass showed maximum genetic advance as percent of mean. Hence, it will be a useful trait for indirect selection to increase grain yield. Plant height and panicle length showed high heritability, relatively better genetic advance as percent of mean. This implies that these characters may be included as a component of indirect selection.

To this end, the results revealed the presence of significant differences for most traits of the tested inbred lines, thus 
indicating the possibility of exploiting the variability in further tef breeding. Thus, recombinant inbred lines like RIL14 have significantly low lodging index, longer panicle, higher number of spikelets per panicle, as well as the highest above ground biomass and grain yield. Genotypes identified with better grain yield related traits and reasonable lodging tolerance require further evaluation and subsequently release to the farming communities in tef growing environments.
Finally, since it is one season experiment, the research needs additional two or more years across wide range of environments to arrive at concrete recommendations for maximization of tef yields. Molecular marker assisted selection in combination with field evaluation of this semidwarf tef inbred recombinant inbred lines traits based on conventional breeding under different environmental conditions also comprehensively recommended.

\section{Appendix}

Table 9. Mean performance of fifteen traits of 49 semi-dwarf tef recombinant inbred lines evaluated over two locations.

\begin{tabular}{|c|c|c|c|c|c|c|c|c|}
\hline RILs & DH & DM & GFP & $\mathbf{P H}$ & PL & CML & PDL & SCL \\
\hline RIL \# 1 & $44.0 n$ & $105.5 \mathrm{a}-\mathrm{m}$ & $61.5 \mathrm{a}$ & $93.7 \mathrm{i}-\mathrm{o}$ & $35.9 a-n$ & $57.8 \mathrm{e}-1$ & 23.4a-h & $11.5 \mathrm{a}-\mathrm{e}$ \\
\hline RIL \# 2 & $52.0 \mathrm{~g}-\mathrm{m}$ & $104.8 \mathrm{f}-\mathrm{m}$ & $52.8 \mathrm{c}-\mathrm{k}$ & $75.0 \mathrm{~s}$ & $29.5 p$ & $45.5 \mathrm{~m}$ & 17.91 & $8.5 \mathrm{f}-\mathrm{h}$ \\
\hline RIL \# 4 & $49.3 \mathrm{~m}$ & $102.8 \mathrm{j}-\mathrm{m}$ & $53.5 \mathrm{~b}-\mathrm{k}$ & $93.8 \mathrm{i}-\mathrm{o}$ & $33.9 \mathrm{~g}-\mathrm{o}$ & $59.9 \mathrm{c}-\mathrm{k}$ & $23.4 \mathrm{a}-\mathrm{h}$ & 11.1a-e \\
\hline RIL \# 5 & $52.0 \mathrm{~g}-\mathrm{m}$ & $104.5 \mathrm{f}-\mathrm{m}$ & $52.5 \mathrm{c}-\mathrm{k}$ & $89.2 n-q$ & $34.0 \mathrm{~g}-\mathrm{o}$ & $55.2 \mathrm{j}-1$ & $21.8 \mathrm{e}-\mathrm{k}$ & $10.5 \mathrm{a}-\mathrm{g}$ \\
\hline RIL \# 6 & $51.8 \mathrm{~h}-\mathrm{m}$ & $105.8 \mathrm{e}-\mathrm{m}$ & $54.0 \mathrm{a}-\mathrm{k}$ & $100.6 \mathrm{c}-\mathrm{k}$ & $37.4 \mathrm{~d}-\mathrm{i}$ & $63.3 a-j$ & $23.2 b-h$ & $11.1 \mathrm{a}-\mathrm{e}$ \\
\hline RIL \# 8 & $57.5 \mathrm{~cd}$ & $106.8 \mathrm{c}-\mathrm{m}$ & $49.3 \mathrm{~g}-\mathrm{m}$ & $110.6 \mathrm{ab}$ & $41.6 b c$ & $69.1 \mathrm{ab}$ & $22.5 c-i$ & $11.1 \mathrm{a}-\mathrm{e}$ \\
\hline RIL \# 12 & $55.8 \mathrm{c}-\mathrm{g}$ & $102.01 \mathrm{~m}$ & $46.3 \mathrm{k}-\mathrm{m}$ & $78.1 \mathrm{rs}$ & 31.5op & $46.6 \mathrm{~m}$ & $19.3 \mathrm{i}-1$ & $7.7 \mathrm{~h}$ \\
\hline RIL \# 14 & $62.5 \mathrm{a}$ & $115.5 \mathrm{a}$ & $53.0 \mathrm{c}-\mathrm{k}$ & $116.0 \mathrm{a}$ & $46.5 \mathrm{a}$ & $69.5 \mathrm{a}$ & $24.0 \mathrm{a}-\mathrm{h}$ & 11.1a-e \\
\hline RIL \# 15 & $50.5 \mathrm{k}-\mathrm{m}$ & $101.81 \mathrm{~m}$ & $51.3 \mathrm{e}-\mathrm{m}$ & $98.3 d-n$ & $34.7 \mathrm{f}-\mathrm{o}$ & $63.6 \mathrm{a}-\mathrm{i}$ & $23.7 \mathrm{a}-\mathrm{h}$ & $11.0 \mathrm{a}-\mathrm{e}$ \\
\hline RIL \# 16 & $53.5 \mathrm{e}-\mathrm{k}$ & $103.5 \mathrm{~h}-\mathrm{m}$ & $50.0 \mathrm{f}-\mathrm{m}$ & $96.4 \mathrm{~g}-\mathrm{o}$ & $34.1 \mathrm{~g}-\mathrm{o}$ & $62.3 a-j$ & $24.9 \mathrm{a}-\mathrm{k}$ & $9.2 \mathrm{a}-\mathrm{h}$ \\
\hline RIL \# 19 & $52.3 \mathrm{f}-\mathrm{m}$ & $109.5 a-1$ & 57.3a-f & $99.3 \mathrm{~d}-1$ & $32.9 \mathrm{j}-\mathrm{p}$ & $66.4 a-f$ & $23.7 \mathrm{a}-\mathrm{h}$ & $10.1 \mathrm{a}-\mathrm{g}$ \\
\hline RIL \# 20 & $54.5 \mathrm{~d}-\mathrm{j}$ & $103.3 \mathrm{i}-\mathrm{m}$ & $48.8 \mathrm{i}-\mathrm{m}$ & $92.9 \mathrm{j}-\mathrm{o}$ & $35.6 \mathrm{e}-\mathrm{o}$ & $57.3 \mathrm{j}-1$ & $24.9 \mathrm{a}-\mathrm{f}$ & $10.7 \mathrm{a}-\mathrm{f}$ \\
\hline RIL \# 21 & $55.8 \mathrm{c}-\mathrm{g}$ & $104.0 \mathrm{~g}-\mathrm{m}$ & $48.3 \mathrm{i}-\mathrm{m}$ & $82.2 \mathrm{q}-\mathrm{s}$ & $32.5 n-p$ & $49.71 \mathrm{~m}$ & 20.6h-1 & $7.7 \mathrm{~h}$ \\
\hline RIL \# 22 & $52.8 \mathrm{f}-\mathrm{m}$ & $105.8 \mathrm{a}-\mathrm{m}$ & $53.0 \mathrm{c}-\mathrm{k}$ & 93.6i-o & $35.3 \mathrm{e}-\mathrm{o}$ & $58.3 \mathrm{~d}-1$ & 23.9a-h & $9.4 \mathrm{e}-\mathrm{h}$ \\
\hline RIL \# 24 & $56.8 \mathrm{c}-\mathrm{e}$ & $106.0 \mathrm{~d}-\mathrm{m}$ & $49.3 \mathrm{~g}-\mathrm{m}$ & $97.4 \mathrm{~g}-\mathrm{o}$ & $38.6 b-f$ & $58.8 \mathrm{~d}-\mathrm{k}$ & $20.4 h-1$ & $11.8 \mathrm{a}-\mathrm{d}$ \\
\hline RIL \# 25 & $58.8 \mathrm{bc}$ & $103.3 \mathrm{i}-\mathrm{m}$ & $44.51 \mathrm{~m}$ & $101.6 c-j$ & $39.5 b-e$ & $62.1 \mathrm{a}-\mathrm{j}$ & $20.4 \mathrm{~h}-1$ & $11.0 \mathrm{a}-\mathrm{e}$ \\
\hline RIL \# 27 & $52.8 \mathrm{f}-\mathrm{m}$ & $108.0 \mathrm{a}-\mathrm{m}$ & $55.3 \mathrm{a}-\mathrm{i}$ & 93.4i-o & $33.1 \mathrm{e}-\mathrm{p}$ & $60.3 \mathrm{~b}-\mathrm{k}$ & $24.3 \mathrm{a}-\mathrm{g}$ & $9.2 \mathrm{e}-\mathrm{h}$ \\
\hline RIL \# 28 & $61.5 \mathrm{ab}$ & $113.5 a-d$ & $52.0 \mathrm{c}-1$ & $106.6 b-f$ & $42.0 \mathrm{bc}$ & $64.6 \mathrm{a}-\mathrm{i}$ & $20.8 \mathrm{~g}-1$ & $11.0 \mathrm{a}-\mathrm{e}$ \\
\hline RIL \# 33 & 51.0i-m & $102.01 \mathrm{~m}$ & $51.0 \mathrm{a}-\mathrm{m}$ & $97.6 \mathrm{~g}-\mathrm{o}$ & $37.0 \mathrm{~d}-\mathrm{k}$ & $60.7 a-j$ & $22.9 \mathrm{~b}-\mathrm{h}$ & $9.4 d-h$ \\
\hline RIL \# 41 & $54.3 \mathrm{~d}-\mathrm{k}$ & $104.0 \mathrm{~g}-\mathrm{m}$ & $49.8 \mathrm{f}-\mathrm{m}$ & $98.8 \mathrm{~d}-1$ & $38.8 b-f$ & $60.0 \mathrm{~b}-\mathrm{k}$ & $22.8 b-i$ & $12.2 \mathrm{a}$ \\
\hline RIL \# 44 & $53.5 \mathrm{e}-\mathrm{k}$ & $103.3 \mathrm{i}-\mathrm{m}$ & $49.8 \mathrm{f}-\mathrm{m}$ & $106.9 \mathrm{~b}-\mathrm{d}$ & $40.8 b-d$ & $66.1 \mathrm{a}-\mathrm{g}$ & $25.5 a-d$ & $10.8 \mathrm{a}-\mathrm{e}$ \\
\hline RIL \# 45 & $54.5 \mathrm{~d}-\mathrm{j}$ & $111.3 \mathrm{a}-\mathrm{h}$ & $56.8 \mathrm{a}-\mathrm{h}$ & $102.2 \mathrm{~b}-\mathrm{i}$ & $35.8 \mathrm{e}-\mathrm{o}$ & $66.4 a-f$ & 23.5a-h & $10.6 a-f$ \\
\hline RIL \# 48 & $54.5 \mathrm{~d}-\mathrm{j}$ & $106.0 \mathrm{~d}-\mathrm{m}$ & $51.5 \mathrm{~d}-\mathrm{m}$ & $103.8 \mathrm{~b}-\mathrm{h}$ & $37.2 \mathrm{~d}-\mathrm{i}$ & 66.7a-e & $24.5 \mathrm{a}-\mathrm{f}$ & $10.1 \mathrm{a}-\mathrm{g}$ \\
\hline RIL \# 52 & $55.5 \mathrm{c}-\mathrm{h}$ & $108.0 \mathrm{a}-\mathrm{m}$ & $52.5 \mathrm{c}-\mathrm{k}$ & $105.0 \mathrm{~b}-\mathrm{g}$ & $36.8 \mathrm{~d}-1$ & $68.2 \mathrm{a}-\mathrm{c}$ & $24.8 \mathrm{a}-\mathrm{f}$ & $10.1 \mathrm{a}-\mathrm{g}$ \\
\hline RIL \# 57 & $55.8 \mathrm{c}-\mathrm{g}$ & $102.8 \mathrm{j}-\mathrm{m}$ & $47.0 \mathrm{j}-\mathrm{m}$ & $95.5 \mathrm{~h}-\mathrm{o}$ & $37.9 \mathrm{c}-\mathrm{h}$ & $57.7 \mathrm{e}-1$ & $25.0 \mathrm{a}-\mathrm{f}$ & $11.2 \mathrm{a}-\mathrm{e}$ \\
\hline RIL \# 58 & $50.8 \mathrm{j}-\mathrm{m}$ & $110.0 \mathrm{a}-\mathrm{k}$ & $59.3 a-d$ & $97.8 \mathrm{f}-\mathrm{o}$ & $37.1 \mathrm{~d}-\mathrm{j}$ & $60.8 a-j$ & $24.3 \mathrm{a}-\mathrm{g}$ & $11.1 \mathrm{a}-\mathrm{e}$ \\
\hline RIL \# 68 & $51.5 \mathrm{i}-\mathrm{m}$ & $103.3 \mathrm{i}-\mathrm{m}$ & $51.8 \mathrm{c}-1$ & $98.0 \mathrm{e}-\mathrm{n}$ & $37.3 \mathrm{~d}-\mathrm{i}$ & $60.7 a-j$ & $26.2 \mathrm{ab}$ & $9.9 \mathrm{a}-\mathrm{h}$ \\
\hline RIL \# 75 & $54.0 \mathrm{~d}-\mathrm{k}$ & $102.3 \mathrm{k}-\mathrm{m}$ & $48.3 \mathrm{i}-\mathrm{m}$ & $89.4 m-q$ & 32.61-p & $56.8 \mathrm{~h}-1$ & $25.0 \mathrm{a}-\mathrm{f}$ & $10.2 \mathrm{a}-\mathrm{g}$ \\
\hline RIL \# 160 & $54.8 \mathrm{~d}-\mathrm{i}$ & $101.3 \mathrm{~m}$ & $46.5 \mathrm{j}-\mathrm{m}$ & $95.3 \mathrm{~h}-\mathrm{o}$ & $32.2 n-p$ & 63.1a-j & $22.1 \mathrm{c}-\mathrm{k}$ & $10.7 \mathrm{a}-\mathrm{f}$ \\
\hline RIL \# 161 & $49.51 \mathrm{~m}$ & $103.0 \mathrm{j}-\mathrm{m}$ & $53.5 \mathrm{~b}-\mathrm{k}$ & $99.0 \mathrm{~d}-1$ & $37.2 \mathrm{~d}-\mathrm{i}$ & $61.8 \mathrm{a}-\mathrm{j}$ & 23.9a-h & $10.5 \mathrm{a}-\mathrm{g}$ \\
\hline RIL \# 162 & $52.8 \mathrm{f}-\mathrm{m}$ & $101.81 \mathrm{~m}$ & 49.0h-m & 91.51-f & $35.9 \mathrm{e}-\mathrm{n}$ & $55.7 \mathrm{i}-1$ & $23.5 a-h$ & $9.7 b-h$ \\
\hline RIL \# 166 & $53.5 \mathrm{e}-\mathrm{k}$ & $101.81 \mathrm{~m}$ & 48.3i-m & $91.11-\mathrm{k}$ & $32.9 \mathrm{j}-\mathrm{p}$ & $58.3 \mathrm{~d}-1$ & $25.7 \mathrm{a}-\mathrm{c}$ & $11.3 \mathrm{a}-\mathrm{e}$ \\
\hline RIL \# 169 & $62.5 \mathrm{a}$ & $114.5 \mathrm{ab}$ & $52.0 \mathrm{c}-1$ & $108.9 \mathrm{a}-\mathrm{c}$ & $41.5 b c$ & $67.4 \mathrm{a}-\mathrm{d}$ & $21.7 \mathrm{e}-\mathrm{k}$ & $10.9 \mathrm{a}-\mathrm{e}$ \\
\hline RIL \# 171 & $52.5 \mathrm{f}-\mathrm{m}$ & $112.0 \mathrm{a}-\mathrm{f}$ & $59.5 \mathrm{a}-\mathrm{c}$ & 98.9d-1 & $38.1 \mathrm{c}-\mathrm{g}$ & $60.8 \mathrm{a}-\mathrm{j}$ & 23.9a-h & $10.5 \mathrm{a}-\mathrm{g}$ \\
\hline RIL \# 171 & $52.5 \mathrm{f}-\mathrm{m}$ & $112.0 \mathrm{a}-\mathrm{f}$ & $59.5 \mathrm{a}-\mathrm{c}$ & $98.9 \mathrm{~d}-1$ & $38.1 \mathrm{c}-\mathrm{g}$ & $60.8 \mathrm{a}-\mathrm{j}$ & 23.9a-h & $10.5 \mathrm{a}-\mathrm{g}$ \\
\hline RIL \# 172 & $51.0 \mathrm{i}-\mathrm{m}$ & $102.8 \mathrm{j}-\mathrm{m}$ & $51.8 \mathrm{c}-1$ & $88.90-\mathrm{q}$ & $31.8 n-p$ & $57.2 \mathrm{~g}-1$ & $21.6 \mathrm{f}-\mathrm{k}$ & $9.5 c-h$ \\
\hline RIL \# 174 & $54.8 \mathrm{~d}-\mathrm{i}$ & $104.3 \mathrm{f}-\mathrm{m}$ & $49.5 \mathrm{f}-\mathrm{m}$ & $97.0 \mathrm{~g}-\mathrm{n}$ & $34.6 \mathrm{f}-\mathrm{o}$ & $62.4 a-j$ & $25.4 \mathrm{a}-\mathrm{e}$ & $12.0 \mathrm{ab}$ \\
\hline RIL \# 175 & $55.5 \mathrm{c}-\mathrm{h}$ & $112.8 \mathrm{a}-\mathrm{e}$ & 57.3a-f & $106.8 \mathrm{~b}-\mathrm{a}$ & $42.5 b$ & $64.4 \mathrm{a}-\mathrm{i}$ & $22.8 b-i$ & $11.9 \mathrm{a}-\mathrm{c}$ \\
\hline RIL \# 178 & $58.8 \mathrm{bc}$ & $102.5 \mathrm{j}-\mathrm{m}$ & $43.8 \mathrm{~m}$ & $78.1 \mathrm{rs}$ & 33.6h-p & $44.5 \mathrm{~m}$ & $18.8 \mathrm{kl}$ & $10.3 \mathrm{a}-\mathrm{g}$ \\
\hline RIL \# 179 & $52.0 \mathrm{~g}-\mathrm{m}$ & $110.3 a-j$ & $58.3 \mathrm{a}-\mathrm{e}$ & $99.6 \mathrm{~d}-1$ & $34.8 \mathrm{f}-\mathrm{o}$ & $64.9 \mathrm{a}-\mathrm{h}$ & $25.5 a-d$ & $11.5 \mathrm{a}-\mathrm{e}$ \\
\hline RIL \# 180 & $53.0 \mathrm{e}-1$ & $101.81 \mathrm{~m}$ & $48.8 \mathrm{i}-\mathrm{m}$ & $92.2 \mathrm{k}-\mathrm{o}$ & $32.5 \mathrm{~m}-\mathrm{p}$ & $59.7 \mathrm{c}-\mathrm{k}$ & $27.0 \mathrm{a}$ & $9.7 b-h$ \\
\hline RIL \# 182 & $53.3 \mathrm{e}-\mathrm{k}$ & $103.3 \mathrm{i}-\mathrm{m}$ & $50.0 \mathrm{f}-\mathrm{m}$ & $92.3 \mathrm{k}-\mathrm{o}$ & $33.9 \mathrm{~g}-\mathrm{o}$ & $58.4 \mathrm{~d}-1$ & $24.9 a-f$ & $10.2 \mathrm{a}-\mathrm{g}$ \\
\hline RIL \# 185 & $57.5 \mathrm{dc}$ & $114.3 \mathrm{a}-\mathrm{c}$ & $56.8 \mathrm{a}-\mathrm{h}$ & $97.8 \mathrm{f}-\mathrm{o}$ & $32.7 \mathrm{k}-\mathrm{p}$ & 65.1a-h & $21.9 \mathrm{~d}-\mathrm{k}$ & $10.9 \mathrm{a}-\mathrm{e}$ \\
\hline RILs & SCD & BP & SP & SBM & \multicolumn{2}{|c|}{ GY } & HI & $\mathbf{L i}$ \\
\hline RIL \# 1 & $1.7 \mathrm{f}-\mathrm{h}$ & $24.3 \mathrm{e}-\mathrm{i}$ & 408.6h-o & $7165.9 \mathrm{e}-\mathrm{i}$ & \multicolumn{2}{|c|}{$1888.8 \mathrm{c}-\mathrm{k}$} & $27.1 \mathrm{a}-\mathrm{d}$ & $67.5 a-c$ \\
\hline RIL \# 2 & $1.8 \mathrm{~b}-\mathrm{g}$ & $25.4 b-i$ & 493.7a-h & $4742.0 \mathrm{op}$ & \multicolumn{2}{|c|}{$1059.3 \mathrm{t}-\mathrm{v}$} & $23.2 \mathrm{~d}-\mathrm{j}$ & $66.0 \mathrm{a}-\mathrm{d}$ \\
\hline RIL \# 4 & $1.6 \mathrm{gh}$ & $25.4 b-i$ & $450.8 \mathrm{c}-1$ & $7154.0 \mathrm{e}-\mathrm{i}$ & \multicolumn{2}{|c|}{$1806.2 \mathrm{e}-\mathrm{m}$} & $26.4 a-f$ & $61.3 \mathrm{a}-\mathrm{g}$ \\
\hline RIL \# 5 & $1.7 \mathrm{f}-\mathrm{h}$ & $24.1 \mathrm{f}-\mathrm{i}$ & $518.2 \mathrm{a}-\mathrm{d}$ & $7436.1 \mathrm{~d}-\mathrm{h}$ & \multicolumn{2}{|c|}{$1521.8 \mathrm{k}-\mathrm{r}$} & $20.9 \mathrm{~g}-\mathrm{k}$ & $67.5 \mathrm{a}-\mathrm{c}$ \\
\hline RIL \# 6 & $1.9 \mathrm{~b}-\mathrm{g}$ & $29.2 \mathrm{ab}$ & $475.2 \mathrm{a}-\mathrm{k}$ & $6790.5 \mathrm{f}-\mathrm{k}$ & \multicolumn{2}{|c|}{$1557.8 \mathrm{i}-\mathrm{o}$} & $24.6 a-i$ & $68.8 \mathrm{a}$ \\
\hline RIL \# 8 & $1.9 \mathrm{a}-\mathrm{f}$ & $28.2 \mathrm{a}-\mathrm{f}$ & $403.7 \mathrm{i}-\mathrm{p}$ & $5434.4 m-p$ & \multicolumn{2}{|c|}{ 1309.41-r } & $24.5 \mathrm{a}-\mathrm{i}$ & $47.0 \mathrm{jk}$ \\
\hline RIL \# 12 & $1.8 \mathrm{c}-\mathrm{g}$ & $24.7 \mathrm{c}-\mathrm{i}$ & $377.61-\mathrm{q}$ & $4332.0 \mathrm{pq}$ & \multicolumn{2}{|c|}{$1138.2 \mathrm{r}-\mathrm{V}$} & $27.0 \mathrm{a}-\mathrm{e}$ & $58.8 \mathrm{~d}-\mathrm{h}$ \\
\hline
\end{tabular}




\begin{tabular}{|c|c|c|c|c|c|c|c|}
\hline RILs & SCD & BP & SP & SBM & GY & HI & $\mathbf{L i}$ \\
\hline RIL \# 14 & $2.1 \mathrm{ab}$ & $24.5 \mathrm{a}-\mathrm{i}$ & $438.3 d-1$ & $9671.4 \mathrm{a}$ & $2523.7 \mathrm{a}$ & 26.1a-g & $54.0 \mathrm{f}-\mathrm{j}$ \\
\hline RIL \# 15 & $1.9 \mathrm{~b}-\mathrm{g}$ & $27.2 \mathrm{a}-\mathrm{g}$ & $475.4 \mathrm{a}-\mathrm{k}$ & 6091.9i-n & $1335.5 \mathrm{o}-\mathrm{u}$ & $21.5 \mathrm{f}-\mathrm{k}$ & $60.0 \mathrm{~b}-\mathrm{g}$ \\
\hline RIL \# 16 & $1.8 \mathrm{~b}-\mathrm{g}$ & $24.2 \mathrm{f}-\mathrm{i}$ & $343.0 \mathrm{~m}-\mathrm{q}$ & $6914.4 \mathrm{e}-\mathrm{j}$ & $1446.1 \mathrm{~m}-\mathrm{s}$ & $22.3 \mathrm{~d}-\mathrm{k}$ & $63.0 \mathrm{a}-\mathrm{e}$ \\
\hline RIL \# 19 & $1.7 \mathrm{c}-\mathrm{g}$ & $22.5 \mathrm{i}$ & $331.80-q$ & $6160.6 \mathrm{i}-\mathrm{n}$ & $1067.6 \mathrm{~s}-\mathrm{v}$ & $17.9 \mathrm{k}$ & 39.51 \\
\hline RIL \# 20 & $1.9 \mathrm{~b}-\mathrm{g}$ & $26.0 \mathrm{a}-\mathrm{i}$ & $488.8 \mathrm{a}-\mathrm{i}$ & $5166.0 \mathrm{n}-\mathrm{p}$ & $1212.6 q-u$ & 25.3a-h & $60.5 \mathrm{a}-\mathrm{g}$ \\
\hline RIL \# 21 & $1.7 \mathrm{~d}-\mathrm{h}$ & 23.0hi & $450.7 \mathrm{c}-1$ & $5409.8 \mathrm{~m}-\mathrm{p}$ & $1146.8 \mathrm{r}-\mathrm{v}$ & $21.5 \mathrm{f}-\mathrm{k}$ & $62.0 \mathrm{a}-\mathrm{f}$ \\
\hline RIL \# 22 & $1.7 \mathrm{f}-\mathrm{h}$ & $25.4 \mathrm{~b}-\mathrm{i}$ & 489.3a-i & $5733.0 \mathrm{j}-\mathrm{o}$ & $1371.4 \mathrm{n}-\mathrm{u}$ & $23.9 b-j$ & $51.5 \mathrm{~h}-\mathrm{k}$ \\
\hline RIL \# 24 & $1.8 \mathrm{c}-\mathrm{g}$ & $28.7 \mathrm{a}-\mathrm{d}$ & 485.7a-j & 5537.01-o & $1309.90-u$ & $23.7 c-j$ & $60.8 \mathrm{a}-\mathrm{g}$ \\
\hline RIL \# 25 & $1.9 \mathrm{~b}-\mathrm{g}$ & 26.6a-i & $433.7 \mathrm{~d}-1$ & $7653.2 \mathrm{~d}-\mathrm{g}$ & 1491.51-r & $19.7 \mathrm{i}-\mathrm{k}$ & $65.5 \mathrm{a}-\mathrm{d}$ \\
\hline RIL \# 27 & $1.7 \mathrm{e}-\mathrm{h}$ & $26.1 \mathrm{a}-\mathrm{i}$ & $378.81-q$ & 6159.8i-n & $1431.3 \mathrm{~m}-\mathrm{t}$ & 26.1a-g & $60.3 \mathrm{a}-\mathrm{g}$ \\
\hline RIL \# 28 & $1.9 \mathrm{~b}-\mathrm{g}$ & $28.8 \mathrm{a}-\mathrm{c}$ & $394.3 \mathrm{k}-\mathrm{p}$ & $9039.3 \mathrm{ab}$ & 2208.1a-c & $24.4 \mathrm{a}-\mathrm{i}$ & $62.3 \mathrm{a}-\mathrm{f}$ \\
\hline RIL \# 33 & $1.8 \mathrm{c}-\mathrm{g}$ & $26.5 \mathrm{a}-\mathrm{i}$ & $338.5 n-q$ & $5264.7 \mathrm{~m}-\mathrm{p}$ & $1138.8 \mathrm{r}-\mathrm{v}$ & $23.5 \mathrm{c}-\mathrm{j}$ & $61.8 \mathrm{a}-\mathrm{f}$ \\
\hline RIL \# 41 & $1.8 \mathrm{~b}-\mathrm{g}$ & $29.6 \mathrm{a}$ & $398.8 \mathrm{j}-\mathrm{p}$ & $7917.3 b-f$ & 2191.9a-d & $28.8 \mathrm{a}-\mathrm{c}$ & 64.3a-e \\
\hline RIL \# 44 & $1.8 \mathrm{c}-\mathrm{g}$ & $25.2 b-i$ & $503.5 \mathrm{a}-\mathrm{g}$ & $7090.0 \mathrm{e}-\mathrm{i}$ & 1629.6h-p & $24.0 a-j$ & $61.8 \mathrm{a}-\mathrm{f}$ \\
\hline RIL \# 45 & $1.9 \mathrm{a}-\mathrm{f}$ & $24.9 \mathrm{c}-\mathrm{i}$ & $418.1 \mathrm{~g}-\mathrm{n}$ & $9669.0 \mathrm{a}$ & $2289.7 \mathrm{ab}$ & $23.6 c-j$ & 63.8a-e \\
\hline RIL \# 48 & $1.7 \mathrm{c}-\mathrm{h}$ & $25.1 b-i$ & $534.5 \mathrm{a}-\mathrm{c}$ & $8044.5 \mathrm{~b}-\mathrm{e}$ & $1726.7 \mathrm{f}-\mathrm{n}$ & $21.6 \mathrm{e}-\mathrm{k}$ & $56.8 \mathrm{e}-\mathrm{i}$ \\
\hline RIL \# 52 & $1.9 \mathrm{~b}-\mathrm{g}$ & $25.7 \mathrm{a}-\mathrm{i}$ & $462.5 a-1$ & 6418.3h-m & 1353.0n-u & $21.1 \mathrm{f}-\mathrm{k}$ & $68.8 \mathrm{a}$ \\
\hline RIL \# 57 & $2.0 \mathrm{a}-\mathrm{d}$ & $26.1 \mathrm{a}-\mathrm{i}$ & $504.8 \mathrm{a}-\mathrm{g}$ & $5167.7 n-p$ & $1281.1 \mathrm{p}-\mathrm{u}$ & $25.1 \mathrm{a}-\mathrm{i}$ & $62.8 \mathrm{a}-\mathrm{e}$ \\
\hline RIL \# 58 & $1.9 \mathrm{~b}-\mathrm{g}$ & $27.5 \mathrm{a}-\mathrm{f}$ & $471.5 \mathrm{a}-\mathrm{k}$ & $6690.2 \mathrm{~g}-1$ & $1641.1 \mathrm{~g}-\mathrm{p}$ & $24.9 \mathrm{a}-\mathrm{i}$ & $65.5 \mathrm{a}-\mathrm{d}$ \\
\hline RIL \# 68 & $1.7 \mathrm{~d}-\mathrm{h}$ & $26.5 \mathrm{a}-\mathrm{i}$ & 494.3a-h & $6914.7 \mathrm{a}-\mathrm{g}$ & $1670.1 \mathrm{~g}-\mathrm{o}$ & $24.0 \mathrm{~b}-\mathrm{j}$ & $64.8 \mathrm{a}-\mathrm{e}$ \\
\hline RIL \# 75 & $1.8 \mathrm{c}-\mathrm{g}$ & $28.5 \mathrm{a}-\mathrm{e}$ & 428.4a-m & 4786.2op & $1004.8 \mathrm{uv}$ & $20.8 \mathrm{~g}-\mathrm{k}$ & $44.5 \mathrm{kl}$ \\
\hline RIL \# 160 & $1.7 \mathrm{~d}-\mathrm{h}$ & 27.6a-f & $548.8 \mathrm{a}$ & $6992.2 \mathrm{e}-\mathrm{i}$ & $1621.8 \mathrm{~h}-\mathrm{p}$ & $22.6 \mathrm{~d}-\mathrm{k}$ & $66.3 \mathrm{a}-\mathrm{d}$ \\
\hline RIL \# 161 & $1.8 \mathrm{~b}-\mathrm{g}$ & $25.1 b-i$ & $377.01-\mathrm{q}$ & $3665.9 \mathrm{q}$ & $896.4 \mathrm{v}$ & $24.4 \mathrm{a}-\mathrm{i}$ & 62.3a-f \\
\hline RIL \# 162 & $1.8 \mathrm{c}-\mathrm{g}$ & $25.6 \mathrm{a}-\mathrm{i}$ & $420.8 \mathrm{f}-\mathrm{n}$ & $7027.7 \mathrm{e}-\mathrm{i}$ & 1456.91-r & $22.0 \mathrm{~d}-\mathrm{k}$ & 63.5a-e \\
\hline RIL \# 166 & $1.7 \mathrm{~d}-\mathrm{h}$ & $28.4 \mathrm{a}-\mathrm{e}$ & $393.9 \mathrm{k}-\mathrm{p}$ & 6161.1i-n & 1468.41-r & $26.2 \mathrm{a}-\mathrm{g}$ & 63.5a-e \\
\hline RIL \# 169 & $2.1 \mathrm{a}$ & $24.8 \mathrm{c}-\mathrm{i}$ & $520.9 \mathrm{a}-\mathrm{d}$ & $8542.7 \mathrm{~b}-\mathrm{d}$ & $1548.6 \mathrm{j}-\mathrm{k}$ & $19.0 \mathrm{jk}$ & $50.5 \mathrm{i}-\mathrm{k}$ \\
\hline RIL \# 171 & $1.8 \mathrm{~b}-\mathrm{g}$ & $26.4 \mathrm{a}-\mathrm{i}$ & 399.9j-p & $5664.1 \mathrm{k}-\mathrm{o}$ & $1406.5 n-t$ & $25.7 \mathrm{a}-\mathrm{h}$ & $61.3 \mathrm{a}-\mathrm{g}$ \\
\hline RIL \# 171 & $1.8 \mathrm{~b}-\mathrm{g}$ & $26.4 \mathrm{a}-\mathrm{i}$ & 399.9j-p & $5664.1 \mathrm{k}-\mathrm{o}$ & $1406.5 n-t$ & $25.7 \mathrm{a}-\mathrm{h}$ & $61.3 \mathrm{a}-\mathrm{g}$ \\
\hline RIL \# 172 & $1.8 \mathrm{~b}-\mathrm{g}$ & $25.0 \mathrm{c}-\mathrm{i}$ & $449.5 c-1$ & $6667.0 \mathrm{~g}-1$ & $1551.4 \mathrm{i}-\mathrm{k}$ & 26.4a-f & $67.8 \mathrm{a}-\mathrm{c}$ \\
\hline RIL \# 174 & $1.9 \mathrm{~b}-\mathrm{g}$ & $23.2 \mathrm{~g}-\mathrm{i}$ & $466.6 \mathrm{a}-\mathrm{k}$ & 6990.1 a-i & $1637.5 \mathrm{~g}-\mathrm{p}$ & $24.0 b-j$ & $65.8 \mathrm{a}-\mathrm{d}$ \\
\hline RIL \# 175 & $1.9 \mathrm{a}-\mathrm{f}$ & $27.1 \mathrm{a}-\mathrm{h}$ & $501.0 \mathrm{a}-\mathrm{g}$ & $7790.7 \mathrm{c}-\mathrm{g}$ & $1460.71-\mathrm{r}$ & $18.8 \mathrm{jk}$ & $67.5 \mathrm{a}-\mathrm{c}$ \\
\hline RIL \# 178 & $1.8 \mathrm{c}-\mathrm{g}$ & $25.1 \mathrm{~b}-\mathrm{i}$ & $513.1 \mathrm{a}-\mathrm{e}$ & $4669.90-\mathrm{q}$ & $1274.6 \mathrm{p}-\mathrm{u}$ & 27.1a-d & $58.5 \mathrm{~d}-\mathrm{h}$ \\
\hline RIL \# 179 & $1.9 \mathrm{~b}-\mathrm{g}$ & $25.4 b-i$ & $427.1 \mathrm{e}-\mathrm{m}$ & $7092.5 \mathrm{e}-\mathrm{i}$ & 1954.0b-h & $29.4 \mathrm{a}$ & 66.0a-d \\
\hline RIL \# 180 & $1.7 \mathrm{~d}-\mathrm{h}$ & $24.5 \mathrm{e}-\mathrm{i}$ & $302.9 q$ & 6446.3h-m & $1186.8 \mathrm{q}-\mathrm{v}$ & 20.6h-k & $59.3 \mathrm{c}-\mathrm{h}$ \\
\hline RIL \# 182 & $1.7 \mathrm{c}-\mathrm{g}$ & $27.6 \mathrm{a}-\mathrm{f}$ & $461.7 \mathrm{~b}-1$ & 6413.0h-m & $1566.0 \mathrm{i}-\mathrm{q}$ & $26.2 \mathrm{a}-\mathrm{g}$ & $68.0 \mathrm{ab}$ \\
\hline RIL \# 185 & $1.9 \mathrm{a}-\mathrm{f}$ & $24.2 \mathrm{f}-\mathrm{i}$ & $446.3 \mathrm{~d}-1$ & $8062.1 \mathrm{~b}-\mathrm{e}$ & 2069.4b-f & $25.4 \mathrm{a}-\mathrm{h}$ & $61.0 \mathrm{a}-\mathrm{g}$ \\
\hline
\end{tabular}

Table 9. (Continued).

\begin{tabular}{|c|c|c|c|c|c|c|c|c|}
\hline $\mathrm{RIL}_{\mathrm{s}}$ & DH & DM & GFP & PH & PL & CML & PDL & SCL \\
\hline RIL \# 195 & 53.0e-1 & $113.8 \mathrm{a}-\mathrm{c}$ & 60.8ab & $102.3 \mathrm{~b}-\mathrm{i}$ & $36.8 \mathrm{~d}-\mathrm{m}$ & 65.6a-h & 23.5a-h & $10.2 \mathrm{a}-\mathrm{g}$ \\
\hline RIL \# 203 & $59.0 \mathrm{bc}$ & $107.3 \mathrm{~b}-\mathrm{m}$ & $48.3 \mathrm{i}-\mathrm{m}$ & $96.2 \mathrm{~g}-\mathrm{o}$ & $34.1 \mathrm{~g}-\mathrm{o}$ & 62.1a-j & 23.0b-h & 11.3a-e \\
\hline RIL \# 262 & $51.3 \mathrm{i}-\mathrm{m}$ & $109.5 \mathrm{a}-\mathrm{k}$ & $58.3 \mathrm{a}-\mathrm{e}$ & $79.7 \mathrm{rs}$ & $35.1 \mathrm{f}-\mathrm{o}$ & $44.6 \mathrm{~m}$ & $21.5 \mathrm{f}-\mathrm{k}$ & $8.2 \mathrm{~g}-\mathrm{h}$ \\
\hline Boset & $57.5 \mathrm{dc}$ & $111.5 \mathrm{a}-\mathrm{g}$ & $54.0 \mathrm{a}-\mathrm{k}$ & 98.8d-1 & $33.4 \mathrm{i}-\mathrm{p}$ & $65.5 \mathrm{a}-\mathrm{h}$ & $23.1 \mathrm{~b}-\mathrm{h}$ & $10.8 \mathrm{a}-\mathrm{f}$ \\
\hline DZ-01-192 & $56.0 \mathrm{c}-\mathrm{f}$ & $110.3 a-j$ & $54.3 a-j$ & $108.8 \mathrm{a}-\mathrm{c}$ & $41.5 b c$ & $67.3 \mathrm{a}-\mathrm{d}$ & $24.4 \mathrm{a}-\mathrm{g}$ & $11.0 \mathrm{a}-\mathrm{e}$ \\
\hline GA-10-3 & $54.3 \mathrm{~d}-\mathrm{k}$ & $102.8 \mathrm{j}-\mathrm{m}$ & $48.5 \mathrm{i}-\mathrm{m}$ & $83.5 \mathrm{p}-\mathrm{r}$ & $32.0 n-p$ & $51.5 \mathrm{k}-\mathrm{m}$ & $18.9 \mathrm{j}-1$ & $9.8 \mathrm{~b}-\mathrm{h}$ \\
\hline Local & $54.0 \mathrm{~d}-\mathrm{k}$ & 111.0a-i & $57.0 \mathrm{a}-\mathrm{g}$ & 98.3d-m & $38.2 \mathrm{c}-\mathrm{g}$ & $60.2 \mathrm{~b}-\mathrm{k}$ & $22.3 c-j$ & 9.9a-h \\
\hline Mean & 54.2 & 106.3 & 52.2 & 96.3 & 36.0 & 60.3 & 23.1 & 10.4 \\
\hline $\mathrm{CV}$ & 4.0 & 4.2 & 8.6 & 5.4 & 6.8 & 8.6 & 8.9 & 12.8 \\
\hline Duncan & 0.6 & 1.3 & 1.3 & 1.5 & 0.7 & 1.5 & 0.6 & 0.4 \\
\hline RIL $_{\mathrm{s}}$ & SCD & BP & SP & SBM & \multicolumn{2}{|r|}{ GY } & HI & $\mathbf{L i}$ \\
\hline RIL \# 195 & 1.9a-f & $24.2 \mathrm{f}-\mathrm{i}$ & 545.0ab & $7720.4 \mathrm{~d}-\mathrm{g}$ & \multicolumn{2}{|r|}{ 1924.6b-j } & $25.9 \mathrm{a}-\mathrm{h}$ & $66.3 a-d$ \\
\hline RIL \# 203 & $1.9 \mathrm{a}-\mathrm{e}$ & $25.0 \mathrm{c}-\mathrm{i}$ & $506.5 \mathrm{a}-\mathrm{f}$ & $8422.5 b-d$ & \multicolumn{2}{|r|}{$2006.0 \mathrm{~b}-\mathrm{g}$} & $24.0 a-j$ & $62.3 a-f$ \\
\hline RIL \# 262 & $1.8 \mathrm{c}-\mathrm{g}$ & $24.6 \mathrm{~d}-\mathrm{i}$ & $452.8 \mathrm{c}-1$ & $5223.1 \mathrm{n}-\mathrm{p}$ & \multicolumn{2}{|r|}{$1536.5 \mathrm{k}-\mathrm{q}$} & $29.2 \mathrm{ab}$ & 61.0a-g \\
\hline Boset & $1.8 \mathrm{c}-\mathrm{g}$ & $25.8 \mathrm{a}-\mathrm{i}$ & 473.0a-k & $8502.2 b-d$ & \multicolumn{2}{|r|}{$1830.7 \mathrm{~d}-1$} & $21.7 \mathrm{~d}-\mathrm{k}$ & $64.8 \mathrm{a}-\mathrm{e}$ \\
\hline DZ-01-192 & $2.0 \mathrm{a}-\mathrm{c}$ & 28.1a-f & $389.2 \mathrm{k}-\mathrm{p}$ & 8919.1a-c & \multicolumn{2}{|r|}{ 1927.1b-i } & $21.9 \mathrm{~d}-\mathrm{k}$ & $53.0 \mathrm{~g}-\mathrm{j}$ \\
\hline GA-10-3 & $1.8 \mathrm{c}-\mathrm{g}$ & $24.4 \mathrm{a}-\mathrm{i}$ & $410.5 \mathrm{~h}-\mathrm{o}$ & 5572.81-o & \multicolumn{2}{|r|}{ 1465.11-r } & 26.4a-f & $63.5 \mathrm{a}-\mathrm{e}$ \\
\hline Local & $1.5 \mathrm{~h}$ & $23.3 \mathrm{~g}-\mathrm{i}$ & $322.7 \mathrm{pq}$ & 9047.4ab & \multicolumn{2}{|r|}{$2145.0 \mathrm{~b}-\mathrm{e}$} & 24.7a-i & 64.3a-e \\
\hline Mean & 1.8 & 25.8 & 443.3 & 6737.7 & \multicolumn{2}{|r|}{1565.0} & 24.0 & 61.4 \\
\hline $\mathrm{CV}$ & 8.3 & 9.1 & 11.3 & 10.4 & \multicolumn{2}{|r|}{14.2} & 12.8 & 8.0 \\
\hline Duncan & 0.0 & 0.7 & 14.2 & 199.2 & \multicolumn{2}{|r|}{63.0} & 0.9 & 1.4 \\
\hline
\end{tabular}

*Means with the same letter are not significantly different, $\mathrm{DH}=$ days to heading, $\mathrm{DM}=$ days to maturity, $\mathrm{GFP}=$ grain filling period, $\mathrm{PH}=\mathrm{plant}$ height, $\mathrm{PL}=$ panicle length, $\mathrm{CL}=$ culm length, $\mathrm{PDL}=$ peduncle length, $\mathrm{SCIL}=$ second culm internode length, $\mathrm{SCID}=$ second culm internode diameter, $\mathrm{NBP}=$ no of branches per panicle, $\mathrm{NSP}=$ no of spikelets per panicle, $\mathrm{ABM}=$ above ground biomass $(\mathrm{kg} / \mathrm{ha}), \mathrm{GY}=$ grain yield $(\mathrm{kg} / \mathrm{ha}), \mathrm{HI}=$ harvest index $(\%), \mathrm{LI}=\mathrm{lodging}$ index, $\mathrm{CV}=$ coefficient of variation (\%) and $\mathrm{RIL}_{\mathrm{s}}=$ Recombinant inbred lines. 


\section{References}

[1] Stallknecht, G. F., Gilbertson, K. M. and Eckhoff, J. L., 1993. Teff: Food crop for humans and animals. New crops. Wiley, New York, 5, 231-234.

[2] Yu, J. K., Kantety, R. V., Graznak, E., Benscher, D., Tefera, H. and Sorrells, M. E., 2006. A genetic linkage map for tef [Eragrostis tef (Zucc.) Trotter]. Theoretical and applied genetics, 113 (6): 1093-1102.

[3] Vavilov NI., 1951. The Origin, Variation, Immunity and Breeding of Cultivated Plants. Translated from the Russian by K. Starrchester, New York: The Ronald Press Co.

[4] Seyfu Ketema, 1993. Tef (Eragrostis tef): Breeding, Genetic Resources, Agronomy, Utilization and Role in Ethiopian Agriculture. Institute of Agricultural Research, Addis Ababa, Ethiopia.

[5] Habtamu Ayalew, Tsige Genet, Tadesse Dessalegn and Landuber Wondale, 2011. Multivariate diversity, heritability and genetic advance in tef landraces in Ethiopia. African Crop Science Journal, 19 (3): 201-212.

[6] Alganesh Tessema, 2013. Genetic Resource of Tef in Ethiopia. Pp. 15-20. In: Kebebew Assefa, Solomon Chanyalew and Zarihun Tadele (eds). Achievements and Prospects of Tef Improvement. Proceedings of the Second International Workshop Debre Zeit 7-9 November 2011, Ethiopia. Ethiopian Institute of Agricultural Research, Addis Ababa, Ethiopia and Institute of Plant Sciences, University of Bern, Switzerland.

[7] Seyfu Ketema, 1997. Promoting the Conservation and Use of Underutilized and Neglected Crops, Tef (Eragrostis tef (Zucc.) Trotter). Institute of Plant Genetics and Crop Plant Research, Gatersleben/International Plant Genetic Resource Institute, Rome, Italy.

[8] CSA, 2020. Central Statistics Agency. Federal Democratic Republic of Ethiopia, Agricultural Sample Survey 2019/20 (2012 E.C.). Vol. I. Report on Area and Production of Major Crops (Private Peasant Holdings, Meher season). Statistical Bulletin 278, Addis Ababa, Ethiopia.

[9] Hailu Tefera and Seyfu Ketema, 2001. Production and importance of tef in Ethiopian Agriculture In: Hailu Tefera, Getachew Belay and Sorrells ME (eds) Workshop Proceedings Addis Ababa: Ethiopian Agricultural Research Organization 3-7.

[10] Spaenij-Dekking L, Kooy-Winkelaar Y and Koning F., 2005. The Ethiopian Cereal Tef in Celiac Disease. $N$ Engl $J$ Med 353: 1748-1749.

[11] USDA, 2015. National Nutrient Database for Standard Reference Release, 27. United States Department of Agriculture.

[12] Cheng, A., Mayes, S., Dalle, G., Demissew, S. and Massawe, F., 2017. Diversifying crops for food and nutrition security-a case of tef. Biological Reviews, 92 (1): 188-198.

[13] Kebebew Assefa, Yu, J. K., Zeid M., Getachew Belay, Hailu Tefera, and Sorells, ME., 2011. Breeding tef [Eragrostis tef (Zucc.) trotter]: conventional and molecular approaches. Plant Breeding 130: 1-9.
[14] Alemu Yami, 2013. Tef Straw. A valuable feed resource to improve animal production and productivity. Pp. 233-251. In: Kebebew Assefa, Solomon Chanyalew and Zarihun Tadele (eds). Achievements and Prospects of Tef Improvement. Proceedings of the Second International Workshop Debre Zeit 7-9 November 2011, Ethiopia. Ethiopian Institute of Agricultural Research, Addis Ababa, Ethiopia and Institute of Plant Sciences, University of Bern, Switzerland.

[15] Yifru Tiklu and Hailu Tefera, 2005. Genetic improvement in grain yield potential and associated agronomic traits of tef (Eragrostis tef). Euphytica 141: 247-254.

[16] Kebebew Assefa, Gina Cannarozzi, Dejene Girma, Kamies Rizqah, Solomon Chanyalew, Sonia PlazaWuthrich, Regula Blosch, Abiel, Rendibascher, Suhaile, Refuaden and Zarihun Tadele, 2015. Genetic diversity in tef [Eragrostis tef (Zucc.) Trotter]. Front. Plant Sci. 6: 177.

[17] Tadesse Ebba, 1975. Tef (Eragrostis tef) Cultivars: Morphology and Classification. Part II. Debre Zeit Agricultural Experimental Station. Bull. No. 66 Addis Ababa University, College of Agriculture, Ethiopia.

[18] Zhu, Q., Smith, S. M., Ayele, M., Yang, L., Jogi, A., Chaluvadi, S. R. and Bennetzen, J. L., 2012, Highthroughput discovery of mutations in tef semi-dwarfing genes by next-generation sequencing analysis. Genetics 192: 819-829.

[19] Kebebew Assefa and Zarihun Tadele, 2012. Increasing food production in Africa by boosting the productivity of understudied crops. Agronomy, 2 (4): 240-283.

[20] Jöst M., Esfeld K., Burian, A., Cannarozzi, G., Solomon, Ch., Kuhlemeier C, Kebebew, A. Zarihun, T., 2015. Semidwarfism and lodging tolerance in tef (Eragrostis tef) is linked to a mutation in the $\alpha$-Tubulin 1 gene. Journal of Experimental Botany, 66: 933-944.

[21] Kebebew Assefa, Hailu Tefera, Arnulf Merker, Turineh Kefyalew and Fufa Hundera, 2001a. Variability, heritability and genetic advance in pheno-morphic and agronomic traits of tef [Eragrostis tef (Zucc.) Trotter] germplasm from eight regions of Ethiopia. Hereditas 134: 103-101 113.

[22] Kebebew Assefa, Hailu Tefera, Arnulf Merker, Turineh Kefyalew and Fufa Hundera, 2001b. Quantitative trait diversity in tef [Eragrostis tef (Zucc.) Trotter] germplasm from Central and Northern Ethiopia. Genetic Resources and Crop Evolution 48: 53-61.

[23] Mesfin Abebe, 2007. Nature and management of acid soils in Ethiopia. M.Sc. Thesis Haramaya University, Dire Dawa, Ethiopia.

[24] Esfeld K, Plaza S, Zarihun, T. 2009. Bringing highthroughput techniques to orphan crop of Africa: highlights from tef TIILING project. Journal of Gene Conserve. 8: 803-807.

[25] Ermias Desta, Sharief Hussein, Laing, M., Fantahun Mengistu and Zarihun Tadele, 2017. Screening of ethyl methane sulphonate mutagenized tef [Eragrostis tef (Zucc.) Trotter] population identifies Al-tolerant lines. Journal of Plant Interactions, 12 (1): 170-176. 
[26] Tareke Berhe, Zewdie Gebretsadik, Edwards, S. and Hailu Araya, 2011. Boosting tef productivity using improved agronomic practices and appropriate fertilizer. Pp. 133-140. In: Kebebew Assefa, Solomon Chanyalew and Zarihun Tadele (eds). Achievements and Prospects of Tef Improvement. Proceedings of the Second International Workshop Debre Zeit 7-9 November 2011, Ethiopia. Ethiopian Institute of Agricultural Research, Addis Ababa, Ethiopia and Institute of Plant Sciences, University of Bern, Switzerland.

[27] Likyelesh Gugsa, Sarial, A. K., ¿Lörz, H. and Kumlehn, J., 2006. Gynogenic plant regeneration from un pollinated flower explants of Eragrostis tef (Zuccagni) Trotter. Plant Cell Reports 25: 1287-1293.

[28] MoARD, 2020. Ministry of Agriculture, Plant Variety Release, Protection, and Seed Quality Control Directorate, Crop Variety Register No. 33, Addis Ababa, Ethiopia.

[29] Solomon Chanyalew, 2009. Genetic analyses of agronomic traits of tef (Eragrostis tef) genotypes. Research Journal of Agriculture and Biological Sciences, 6 (6): 912-916.

[30] Solomon Chanyalew, Kebebew Assefa and Gizaw Metaferia, 2013. Phenotypic and molecular diversity in tef. Pp. 21-31. In: Kebebew Assefa, Solomon Chanyalew and Zarihun Tadele (eds). Proceedings of the Second International Workshop Debre Zeit 7-9 November 2011; Ethiopia. Ethiopian Institute of Agricultural Research, Addis Ababa, Ethiopia, Institute of Plant Sciences, University of Bern, Switzerland.

[31] Habte Jifar, Kifle Tesfaye, Kebebew Assefa, Solomon Chanyalew and Zarihun Tadele, 2017. Semi-dwarf tef lines for high seed yield and lodging tolerance in Central Ethiopia. African Crop Science Journal, 25 (4): 419-439.

[32] Habte Jifar, Kebebew Assefa and Zarihun Tadele, 2015. Grain yield variation and association of major traits in brown seeded varieties of tef [Eragrostis tef (Zucc.) Trotter]. Agri. and Food Security 4: 7-16.

[33] Ramburan, S., Zhou, M. and Labuschagne, M. T., 2012. Investigating test site similarity, trait relations and causes of genotype $\times$ environment interactions of sugarcane in the Midlands region of South Africa. Field crops research, 129, 71-80.

[34] Caldicott, J. B. and Nuttall, A. M., 1979. A method for the assessment of lodging in cereal crops. A. Journal of Natural Institute Agricultural Botany, 15: 88-91.

[35] Hartley, H. O., 1950. The maximum F-ratio as a short cut test for heterogeneity of variances. Biometrika 37: 308-312.

[36] Gomez, K. A., and A. A. Gomez., 1984). Statistical Procedures for Agricultural Research. 2nd ed., John Wiley and Sons, Inc., New York, USA.
[37] Manly, B. F. J., 1986. Multivariate Statistical Methods: A Primer. Chapman and Hall, London.

[38] SAS, 2011. Statistical Analysis System, Version 9.3. SAS Institute Inc. Cary, NC, USA.

[39] Falconer, D. S., 1981. Introduction to quantitative genetics (2nd ed.) Long man Inc. New York.

[40] Burton, G. W. and Devane, E. H. (1953). Estimation of heritability in tall Festuca (Festuca arundinacea) from replicated clonal material. Journal of Agronomy, 45: 478481.

[41] Kherdade, P. W. Narkhede, M. N. and Raut, S. K., 1985. Genetic variability studies in chick pea. International chick pea Newsletter 12: 12-13.

[42] Allard, R. W., 1960. Principles of Plant Breeding. 2nd ed. John Wiley and Sons, New York, USA.

[43] Robinson H. F., Comstock R. E. and Harvey P. H., 1954. Elements of biometrical genetics. Concept Publishing Company. New Delhi, India. In: Dabholkar, A. R. (1992). Genetic and phenotypic correlation in corn and their implications in selection. Agron. J. 43: 283-287.

[44] Johnson, H. W., Robinson, H. F. and Comstock R. E. (1955). Estimates of genetic and environmental variability in soybeans. Journal of Agronomy, 47: 314-318.

[45] Falconer, D. S., Mackay, T. F. and Frankham, R., 1996. Introduction to quantitative genetics (4th Eds). Trends in Genetics, 12 (7): 280.

[46] Kebebew Assefa, Arnulf Marker and Hailu Tefera, 2003b. Inter simple sequence repeat (ISSR) analysis of genetic diversity in tef [Eragrostis tef (Zucc.) Trotter]. Hereditas 139: 174-183.

[47] Abel Debebe, Harijat, S. and Hailu Tefera., 2012. Genetic variability and heritability studies in $\mathrm{F}_{4}$ progenies of tef (Eragrostis tef). Asian Journal of Agricultural Sciences, 4 (3): 225-228.

[48] Kebebew Assefa, Seyfu Ketema, Fufa Hundera, Hailu Tefera, and Turineh Kefyalew, 2000. Trait diversity, heritability and genetic advance in selected germplasm lines of tef [Eragrostis tef (Zucc.) Trotter]. Hereditas, 133 (1): 29-37.

[49] Chekole Nigus, Wassu Mohammed, Tebkew Damte, 2016. Genetic variation, correlation and path coefficient analysis in Tef [Eragrostis tef (Zucc.) Trotter] genotypes for yield, yield related traits at Maysiye, Northern Ethiopia. American Journal of Research Communication, 4 (11): 73-102. 